\title{
Determinants of Firm Innovation in Indonesia: The Role of Institutions and Access to Finance
}

\author{
Edo Mahendra ${ }^{\mathrm{a}, *}$, Ubaidillah Zuhdi ${ }^{\mathrm{b}, * *}$, Ratnawati Muyanto ${ }^{\mathrm{c}, * * *}$ \\ a Depart. of International Development, Univ. of Oxford, United Kingdom \& School of Government and Public Policy, Indonesia \\ ${ }^{b}$ Faculty of Management and Economics, Gdansk University of Technology, Poland \\ cInternational Labour Organization, Country Office Indonesia
}

\begin{abstract}
This paper investigates the determinants of firm innovation in Indonesia. Using quality of local regulations index constructed by the Indonesia's Regional Autonomy Watch (KPPOD) as measure of institutions, We found that better institutional quality at the local level was associated with more innovation and that firms experiencing major obstacle in access to finance were less likely to innovate. Access to finance is more critical for small and medium enterprises (SMEs) whereas institutional quality is more important for large firms. The positive impact of better institutions on innovation is asymmetrically distributed. Better local institutional quality disproportionately benefited non-constrained firms.
\end{abstract}

Keywords: Access to Finance; Firm Innovation; Innovation Determinants; Innovation Gap, Institutions

\begin{abstract}
Abstrak
Makalah ini menyelidiki faktor-faktor penentu terjadinya inovasi pada perusahaan di Indonesia. Sebagai proksi kelembagaan digunakan variabel Peraturan Daerah yang dibuat oleh Komite Pemantuan Pelaksanaan Otonomi Daerah (KPPOD). Penelitian ini menemukan bahwa kualitas kelembagaan yang baik pada tingkat daerah erat kaitannya dengan tingkat inovasi yang lebih tinggi dan perusahaan-perusahaan yang mengalami kendala akses keuangan cenderung tidak melakukan inovasi. Faktor akses keuangan lebih menentukan bagi perkembangan inovasi perusahaan perusahaan kecil dan menengah sedangkan kualitas kelembagaan lebih menentukan bagi perusahaan besar. Dampak positif dari kelembagaan yang baik terhadap tingkat inovasi terdistribusikan secara asimetris dan faktor kelembagaan yang baik lebih berdampak positif terhadap perusahaan yang tidak mengalami kendala keuangan.
\end{abstract}

Kata kunci: Akses Keuangan; Inovasi Perusahaan; Faktor Penentu Inovasi; Kesenjangan Inovasi; Kelembagaan

JEL classifications: O38; O53; G38

\section{Introduction}

Innovation is the engine of economic growth. The role of innovation is even more critical once a country has transformed into an emerging economy since innovation is one of the key factors to

\footnotetext{
*Corresponding Address: 3 Mansfield Road, Oxford, OX1 3TB, United Kingdom. E-mail: edo.mahendra@wolfs on .ox .ac . uk.

** Faculty of Management and Economics, Gdansk University of Technology, ul. Narutowicza 11/12, 80-233 Gdansk, Poland. E-mail: zuhdi@zie.pg.gda.pl.

*** E-mail: ratnawati_sp@yahoo.com
}

prevent the country from falling into the middleincome trap. Indonesia, as a rapidly developing economy, is on its way to leap forward to become a global economic powerhouse. However, without giving sufficient attention to identifying impediments to innovative activities, Indonesia may eventually hit the ceiling, and fail to avoid the middleincome trap. The literature focusing on the identification of the determinants of firm innovation, with a specific focus on Indonesia, is still strikingly thin. Moreover, most empirical studies have largely ignored the role of external factors influencing firm's innovative activities. We tried to fill this research gap by conducting an Indonesian-specific study on 
the determinants of innovation at the firm level.

We analysed how institutional quality and access to finance could affect firm innovation in a country with relatively low research and development spending like Indonesia. World Bank data for 2009 showed that the ratio of expenditures for research and development (public and private sector) to total GDP in middle income countries was $1.17 \%$ while Indonesia's ratio was only $0.08 \%$. We defined innovation as product and process innovation. We used local regulations to measure institutional quality since Indonesia had been under a decentralised system where regional innovation system could boost firm innovation. The literature pointed out that regional innovation system could promote firm innovation as the result of interaction of different aspects like entrepreneurship, creativity, and politics. Another factor that is the focus of our paper is access to finance because it determines firm behaviour and decision to engage in innovative activities.

One factor augmenting firm innovation is the firm location in such an area where the institutions supporting innovative process exist. One particular region can be more competitive than other regions due to the positive arrangement of innovative networks and institutions interacting with innovative outputs of regional firms (Cooke 2001). Dean (2000) argued that robust commercial banking system is a pre-condition for successful innovation system such as the Silicon Valley. Rowen (2000) identified that for firms located in Silicon Valley, one of the most important factors for successful regional innovation system is a favourable rule of the game where laws, regulations, and conventions are well governed and induce positive influence to firms. Due to the positive externality of innovation, regulations can also be utilised to even recover the R\&D investment of business (Helm 2006). Huo \& Feng (2010) showed that socio-political coordination intensifies the reciprocal sharing of innovation which, at the expense of job-creation, increases productivity returns.

The literature on firm innovation determinants has traditionally focused more on firm characteristics. As for higher level factors, the emphasis has also been more on industry-level determinants such as market structure. Other external factors such as institutions and access to finance have been largely ignored until recently. This negligence is quite sur- prising since institutions shape the business environment where firms are located and access to finance is crucial as external sources of capital; these are critical for firm activities, including innovative activities. In this paper, we contribute to the literature by showing the empirical evidence of the complex interplay between institutions, access to finance, and firm innovation, as well as how they influence innovation gap among different types of firms.

We structured this paper as follows: In section 2, we discuss the literature review on how institutions can influence firm innovation and how difficulty in access to finance can discourage firms from engaging in R\&D activity. In section 3 , we summarise the position of Indonesia's innovation in a comparative perspective. Section 4 describes the development of local regulations in Indonesia. Section 5 discusses access to finace in Indonesia in comparison with several comparable countries. In section 6 , we describe the data used for the regression analyses as we merged the data from World Bank and KPPOD (Indonesia's Regional Autonomy Watch) as well as the econometric strategies we pursued. In section 7, we present and discuss the results of our empirical exercise. Finally, section 8 concludes.

\section{Literature Review}

Research on innovation determinants have traditionally put more emphasis on the firm-level determinants of innovation. Proxies for firm knowledge, capabilities, skills, and resources are normally used for the analysis of factors that determine firm's innovative activities (Fagerberg 2005). One of the most common research topics is the relationship between firm size, market structure, and innovation (Acs \& Audretsch 1987). It is so because the research on firm innovation determinants has its root on Schumpeterian tradition in which the main hypothesis is that large firms in monopolistic markets are the engines of innovation (Schumpeter 1942). Accordingly, most empirical studies on firm innovation as surveyed by Cohen (2010) have focused more on the influence of firm and industrial characteristics on firm's innovative activities. Meanwhile, other external factors such as institutions have been largely neglected 
in the empirical studies of firm innovation determinants.

Only a few studies have investigated the impact of other external factors such as institutions on innovation at the firm level. One recent attempt to fill the research gap is of Blind (2012) who developed the theoretical framework on how regulations, as an institutional set-up, affect firm innovation. He argued that different types of regulations (economic, social, and institutional) have different effects on innovation. Thus it is important to differentiate the types of regulations in empirical analysis. Another recent attempt to integrate institutions as innovation determinants is provided by Srholec (2011). He argued that innovation is, in principle, a multilevel phenomenon, hence it is necessary to incorporate higher-level factors (external/environment factors) including institutions in the analysis of determinants of firm innovation. Finally, Tebaldi \& Elmslie (2013) argued that crosscountry analyses in the relationship between institutions and innovation are lacking in the literature, and thus provided an estimate on how institutions affect innovation at the country level.

How do we define and measure institutions? The widely accepted definition of institutions is provided by North (1990) who explained that "institutions are the rules of the game in a society or, more formally, are the humanly devised constraints that shape human interaction". It is clear from the definition that the objective of institutions is to establish 'constraints'. Acemoglu \& Robinson (2008) proposed three important dimensions of institutions in which "setting constraints" is one of them. The goal of setting constraints is to influence incentives. It is thus natural to argue that institutions shape incentives-which obviously include the incentives to engage in innovative activities. Surprisingly, this theoretical derivation is heavily underresearched.

Measuring institutions is not an easy task since each country or region may have different understanding and perceptions on what institutions are. Nevertheless, it is possible to measure them with some proxies such as property rights (Knack \& Keefer 1995), corruption level (Mauro 1995), political constraints (Henisz 2000), or a constructed aggregate index (Rodrik, Subramanian \& Trebbi 2004). Glaeser et al. (2004) provided a survey on some common proxies for measuring institutions.
Before Srholec (2011) and Blind (2012), the studies on the role of institutions in the economy had put more emphasis on economic development such as growth or investment. As such, the majority the studies focused more to disentangle the impact of institutions on economic performance of countries. Most studies have found the significant effect of institutions on economic performance. Knack \& Keefer (1995) showed that property rights, as a proxy for institutions, have a positive impact on economic growth. Mauro (1995) found that corruption, as an inverse proxy for quality of institutions, lowers economic growth through investment channel. Another indicator for institutions, entry barriers, was also found to have negative associations with economic performance (Djankov et al. 2002). Regarding the endogeneity issue, Acemoglu, Johnson \& Robinson (2001) demonstrated that the causality runs from institutions to economic performance, hence providing the evidence that the relationship between institutions and economic performance is not merely correlation.

Regulations can also be an appropriate measure of institutions. Anderlini et al. (2013) demonstrated the theoretical exposition that explains the link between legal system and innovation in which more rigid legal system is supportive at early stages of technological development. Meanwhile, some empirical studies have used regulations measures and analysed their effects on economic performance. Djankov et al. (2002) found that heavier regulations of entry (entry barriers) are detrimental to a country's economic performance. More efficient business regulations were also found to promote growth (Djankov, McLiesh \& Ramalho 2006). The effectiveness of regulations also matters. Jalilian, Kirkpatrick \& Parker (2007) defined the quality of regulations as determined by the efficiency and quality of regulations, and demonstrated a strong causal link between these measures of effectiveness of regulation and growth.

With regards to innovation, most studies on innovation determinants have emphasized more on the role of innovation policies instead of regulations. Dolfsma \& Seo (2013) provided the typology of innovation policy and its theoretical relationship with innovation. In addition, 'policy mix' of innovation policy is an important concept that arguably influences innovation activities (Flanagan, Uyarra \& Laranja 2011). Nevertheless, innovation policy is a 
more fluid concept, and does not necessarily capture the full extent of institutions. Innovation policy, as any other policies, is the implementation of laws and regulations and is executed following the rules stipulated in laws and regulations.

The relationship between regulations, as a measure of institutions, and firm innovation has been largely ignored in empirical innovation studies until recently. Existing studies, however, have focused more on specific regulations i.e. technical regulations related to standards and compliance procedures in specific industries. Chataway, Tait \& Wield (2006) analysed regulations in agro- and bio-technology and argued that more discriminating regulatory environment supports innovation. As for the case of pharmaceutical industry, more demanding regulatory intervention is good for innovation (Abraham \& Davis 2007). Most of these studies follow the case study approach. Eventhough case study is laudable for its richness in detailed analysis, it lacks external validity, hence any generalisation based on case studies approach is limited. There are only few exceptions in major publications such as Prieger (2002) who conducted large-N analysis to investigate the effect of the Federal Communications Commission (FCC) regulation on innovation in the US telecommunication industry.

Due to more data availability, more recent studies on institutions and innovation have been able to work with large- $\mathrm{N}$ analysis that allows for some degree of generalisation of results-thus, providing a stronger claim on external validity. At the country level analysis, Tebaldi \& Elmslie (2013) found that institutions explain much of the variations of innovation across countries. Using OECD countries as sample, Blind (2012) showed that the effect of regulations on innovation are mixed depending on the type of regulations. On the other hand, structure of government, i.e., decentralisation level was not found to be a robust predictor of innovation (Taylor 2007). Using multilevel analyses, Srholec (2011) found that democratic institutions are correlated with firm innovation whereas tax regimes with high marginal rates are associated with less firm innovation. In this paper, our measure of institutions is the quality of local regulations in which entry barriers are one of its sub-components. Therefore, our measure of institutions is in a similar vein with Jalilian, Kirkpatrick \& Parker (2007) and Djankov et al. (2002). Theoretically, our measure of regulations is within the concept of 'economic regulation' as defined by Blind (2012).

Another external factor which we focus on in this paper is access to finance. Similar to institutions, the role of finance in innovation empirics has been largely unexplored. In fact, O'Sullivan (2005) surveyed that the empirical literature on innovation has so far neglected the relationship between finance and innovation. This is interesting since Schumpeter himself argued that the creation of credit is essential in spurring innovation, putting emphasis on the critical role of commercial banks. There is ample literature, however, on the role of access to finance on investment activities. Hubbard (1998) surveyed the literature on the relationship between capital market imperfections and investment by firms, and explained that the evidence pointed to the significant role of financial constraints faced by firms and capital investment. Most empirical studies on access to finance have also been more focused on firm growth. Levine (2005) and Beck (2008) provided the surveys on the literature on finance and growth, including growth at firm level. Akin to firm investment, notwithstanding the issue of causality and the fact that most finance and growth empirical studies have been done at the macro or industry level, they demonstrated that finance, including access to finance, matters for firm growth. Therefore, we view the neglect on the role of access to finance in innovation studies as surprising because, like any other firm decisions on resource allocation, firm's financial capability and constraints should matter for innovationrelated capital allocation. In other words, innovative activity is simply a type of capital and resource allocation of firms.

Financing innovative activities is not easy. Although as we argued above innovation is basically just another type of capital allocation by firms, such activity has several differences with typical firm investment activities. Hall \& Lerner (2010) explained that one important feature of innovative activities, which is normally classified under R\&D spending, is that they have a considerably large uncertainty in their outputs. Although the level of uncertainty and the probability of failure decrease over time as innovation projects near completion, innovative activities are at the higher end of the probability of experiencing failure compared with other investment activities in general. If we include quality of institutions in the calculus, then developing countries 
are disproportionately worse off. Notwithstanding the perverse impact of frictions in credit markets, worse institutional quality surrounding firm's business environment increases the uncertainty of innovative activities. Hence, a firm under such condition may find it difficult to secure capital resources to finance innovation.

Why does access to finance matter for innovation? In theory, there are three possible explanations on why firms fail to secure financing and thus face obstacles in accessing finance for their innovation (Hall \& Lerner 2010): (i) asymmetric information between business (inventor/entrepreneur) and investor, (ii) moral hazard on the part of business due to separation of ownership and management, and (iii) tax considerations that drive a wedge between external finance and finance by retained earnings. In accordance with the context of this paper, the first explanation on asymmetric information between potential creditors and debtors is more relevant. Frictions in the credit market result in higher costs of borrowing charged by creditors such as commercial banks. Such frictions are caused by asymmetric information existing in the credit market. If the information asymmetries are large enough, it may eventually lead to the condition where financial institutions set very high costs of borrowing which make it difficult for firms to secure financing. Moreover, in this case, firms which are relatively more dependent on external financing to finance their innovation are disproportionately affected. In other words, frictions in the credit markets due to asymmetric information may lead to less firm innovation.

Although the major literature on access to finance and innovation in general has been quite lacking, some studies have researched on the role of specific types of financing on innovation such as venture capital. Florida \& Kenney (1988) argued for the prominent role of venture capital in spurring innovation in new high technology businesses. Kortum \& Lerner (2000) found that venture capital financing has been supportive in promoting product innovation as measured by patented inventions in the United States. However, it seems that such type of financing (venture capital) is more apparent in the case of US. Even in the developed parts of Europe, venture capital financing that supports innovative firms has not relatively been that prominent and that Europe is way behind their cross-Atlantic counterpart (Murray \& Lott 1995; Bottazzi \& Da
Rin 2002). As for the case of developing countries, with much limited pool of financial resources available, the access and availability to venture capital is severely limited. In fact, in the analysis of venture capital funding determinants, Jeng \& Wells (2000) could only use 21 sample of developed countries in their analysis, leaving out developing countries.

Most developing countries have underdeveloped financial systems. In this group of countries, the majority of countries are bank-based economies (Demirguc-Kunt \& Levine 1999). Indonesia is classified as bank-based economy (Demirguc-Kunt \& Maksimovic 2002). In such case, the issue of access to finance is a more traditional one. Since the market-based financial system is still relatively thin in Indonesia, Indonesian firms who need financing are largely dependent on loans provided by commercial banks. As we discuss in section 5 , in this type of financing, interest rates as well as institutional infrastructure of the credit markets such as creditors protection and information are critical to reduce frictions in the financial intermediation processes that may lead to higher costs of borrowing.

Amidst the general lack of research in the literature on access to finance and innovation, some studies have attempted to fill the gap. Gorodnichenko \& Schnitzer (2013) provided the theoretical explanations on why firms lacking access to finance are less likely to engage in innovative activities. They also showed empirically that financially constrained domestic firms are unambiguously restrained to innovate. For innovation in ICT industry, a market-based financial system, including a welldeveloped venture capital market, is essential in smoothing financial intermediation and to provide access to finance for firm innovation (Houben \& Kakes 2002). Hyytinen \& Toivanen (2005) showed that financial constraints are detrimental for innovation, and that government intervention to address the perverse impact of imperfect credit markets is necessary to promote firm innovative activities.

Nevertheless, most research on access to finance and firm innovation has focused more on OECD countries, and that studies focusing on developing countries have largely been non-existent (Gorodnichenko \& Schnitzer 2013). Some notable exceptions, nonetheless, exist. For instance, Sharma (2007) showed that financial development matters in supporting firm innovation in developing coun- 
tries. Meanwhile, Ayyagari, Demirguc-Kunt \& Maksimovic (2011) found that access to finance, as measured by indicators of possession of various credit lines and borrowing, for firms in developing countries is associated with more innovative activities. Finally, Gorodnichenko \& Schnitzer (2013) analysed the data for Eastern Europe and former Soviet Union which are composed mostly of developing countries. In general, however, there is still a large research gap on the role of access to finance on firm innovation.

Quality of institutions and access to finance are not independent in influencing innovation. Hyytinen \& Toivanen (2005) showed the empirical evidence supporting the hypothesis that government intervention helped to address credit market imperfections due to financial frictions. In addition, Morck, Yeung \& Yu (2000) demonstrated that quality of institutions explain why the allocation of capital flows toward growth potential firms and away from firms with less potentials. This evidence shows that the effect of better institutional quality may not be the same for firms facing obstacles in access to finance vis-a-vis those who are able to obtain external financing.

On the one hand, in a well-developed financial system and minimal frictions in its credit market, smaller firms may benefit more from financial development since financial innovations in the credit market may moderate the collateral requirement which disproportionately benefits smaller firms (Sharma 2007). In this scenario, SMEs are thus better off from larger pool of financial resources available. Benfratello, Schiantarelli \& Sembenelli (2008) showed that banking development supports innovation, and that smaller firms and sectors that are more dependent on external financing are disproportionately benefited.

On the other hand, the significant presence of SMEs also means that the costs of gathering credit quality information are relatively higher since smaller firms tend to have much less sophisticated reporting on their performances. Accordingly, this may result in the greater degree of asymmetric information in the credit market. Hence, in this scenario, smaller firms are disproportionately worse off. Herrera \& Minetti (2007) showed that the extent of banks having more information regarding the credit quality of debtors is positively associated with firm innovation.
Our discussions have shown that quality of institutions and access to finance matter for firm innovation. We expected that better local institutional quality, as proxied by local regulations, is associated with more innovation. Furthermore, we hypothesized that firms facing obstacles in access to finance are less likely to be involved in innovative activities. Finally, due to the presence of significant frictions in Indonesia's credit markets as well as lack of institutional quality in the financial markets (as discussed in section 5), firms not facing obstacles in access to finance are more likely to benefit more from better institutional environment, thus leading to larger gap in innovative capabilities between constrained and non-constrained firms due to the asymmetric impact of local institutions towards firms that are more able in dealing with formalities including the capability to provide information in credit quality. In relation to that, we thus expected that for larger firms, the quality of regulations matters more for their innovation whereas for smaller firms (SMEs), access to finance is a more relevant issue.

\subsection{Innovation Performance in Indone- sia: A Comparative View}

This section discusses the position of IndonesiaâÁŹs innovation in the world. To do so, we conducted a comparative analysis approach. We picked three major developing Southeast Asian countries: Malaysia, Thailand, and Philippines, and two economically powerful Asian countries: China and India, as comparison countries. According to Schwab and Martin (2012), innovation is one of the pillars of global competitiveness. Innovation as a competitiveness pillar is defined by several components. These components are (i) capacity for innovation, (ii) quality of scientific research institutions, (iii) company spending on research and development (R\&D), (iv) university-industry collaboration in R\&D, ( $v$ ) government procurement of advanced technology products, (vi) availability of scientists and engineers, (vii) Patent Cooperation Treaty (PCT) patent applications, and (viii) intellectual property protection. Schwab and Martin (2012) have used these eight components to contruct the innovation index for the global competitiveness index (GCl) of the World Economic Forum. For our analysis, we looked into the innovation score of the 


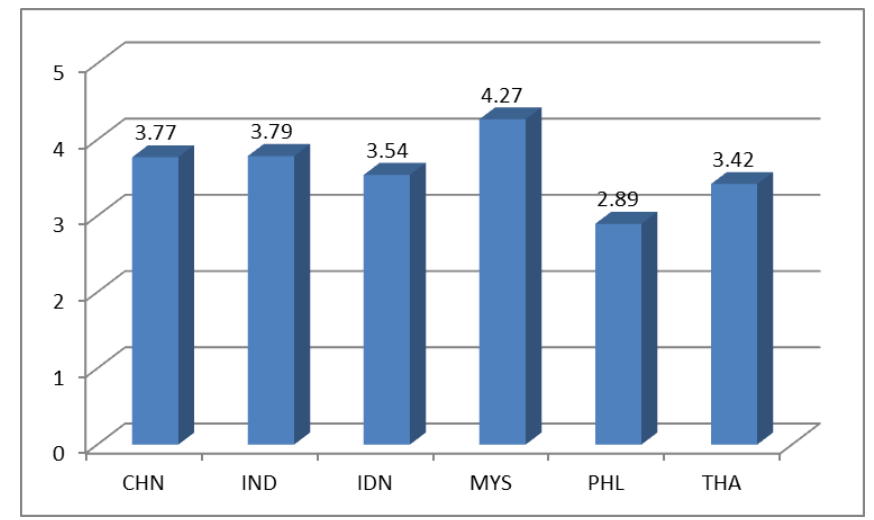

Figure 1: GCI-Innovation Component Score (average, 2005-2011) Source: Global Competitiveness Report

$\mathrm{GCl}$ and the capacity for innovation (component (i)) to see how Indonesia fares in comparison with other comparable countries. Our time frame for the analysis in this section is 2005-2011.

We started by analysing how innovation in general in Indonesia compares with the aforementioned countries. We used the innovation part of $\mathrm{GCl}$ where the score ranges from 1 to 7 (higher score means better). As we can see in Figure 1, in comparison with other major developing Asian countries, Indonesia scores quite well. Compared with other major developing Southeast Asian countries, only Malaysia posts higher score in innovationthus Indonesia is better compared with Thailand and the Philippines. Nevertheless, Indonesia is still slightly left behind China and India, the two rising superpowers of Asia.

The average score, however, does not tell much about the progress of innovation performance of these countries. To see how innovation has progressed in Indonesia, we set the year 2005 as our base year $(2005=100)$. Therefore, we could further analyse whether innovation progress in Indonesia has outperformed its comparable countries in Asia. Figure 2 displays an even rosier picture than Figure 1. Between 2005 and 2011, innovation in Indonesia had been growing quite remarkably, beaten only by China which grew very strongly. As we can see, some countries like India and Philippines have shown decelerating trend in their innovation performance according to the Global Competitiveness report. Hence, Figure 1 and 2 provide an optimistic overview of innovation performance in Indonesia. Although the average innovation performance of Indonesia since 2005 only put Indonesia in mid-table position, the trend in 2005-2011, nonetheless, displayed an encouragingly positive signal on the progress of Indonesia's innovation performance.

The GCl pillars are interretaled with one another. For example, according to Schwab \& Sala-i-Martin (2012), innovation cannot be separated from the availability of well-educated and trained workforce. Countries with better educated citizens are more likely to have greater capacity to innovate. Thus, more quality in the human capital provides the necessary condition for innovation. To know how human capital and innovation relate, we look into the GCl scores for 'higher education and training' pillar and plot them with the 'capacity for innovation' scores of the innovation pillar. 'Capacity for innovation' index scores range from 1 (companies obtain technology exclusively from licensing or imitating foreign companies) to 7 (companies obtain technology by conducting formal research and pioneering their own new products and processess). Hence, higher scores imply more capability of the private sector to conduct innovative in-house activities whereas lower scores indicate higher dependency of the private sector on foreign sources.

Figure 3 plots the relationship between innovation capacity and higher ecudation and training. Malaysia is a prime example of success. In accordance with better human capital quality, the private sector in Malaysia has a relatively robust innovation capacity, which means their innovation activities are more domestically resourced. On the other hand, China and India have relatively strong 


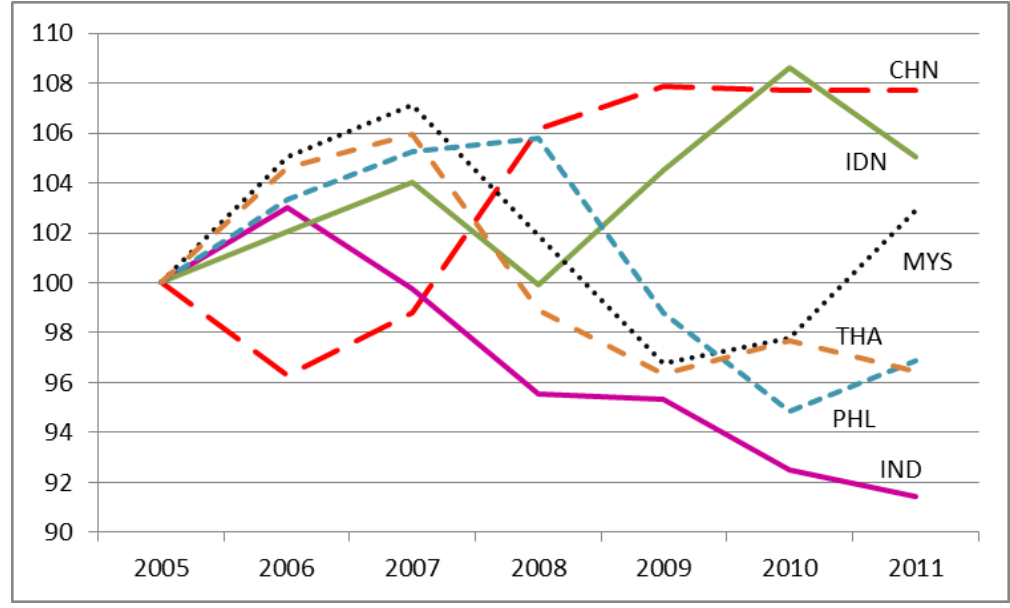

Figure 2: Progress of GCI-Innovation Component Score (2005=100) Source: Global Competitiveness Report

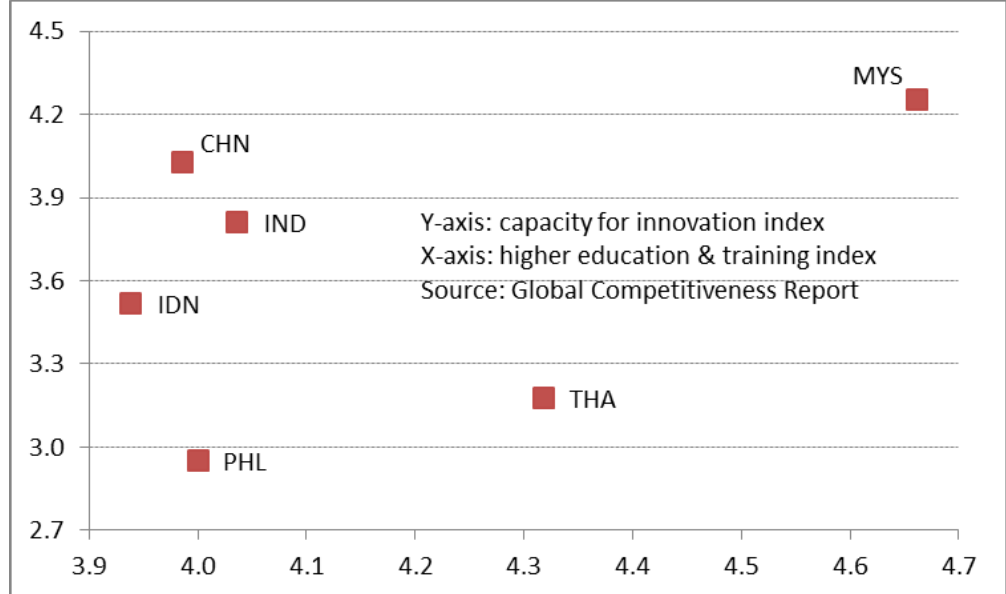

Figure 3: Innovation Capacity and Human Capital (average, 2005-2011) Source: Global Competitiveness Report 
scores on capacity for innovation index amidst relatively mediocre scores on higher education and training. Therefore, China and India are the instances where innovation activities are mostly done through licensing or imitation. As for Indonesia, given the fact that it has the lowest position on human capital while being able to score the midtable for innovation capacity, it gives the signal that Indonesia's capacity for innovation is more similar to China and India. In other words, the capacity for innovation in Indonesia is more likely to come from licensing or imitation instead of originally resourced innovative activities. The ideal path is definitely to follow Malaysia. In other words, better quality in higher education and training should be prioritised to boost in-house and original innovation.

This section reviews the state and development of innovation performance in Indonesia over the 2005-2011 period. In general, Indonesia's innovation performance has been relatively well positioned against other major developing Asian economies (Figure 1). In fact, encouraging sign is clearly visible since Indonesia, together with China, are the two economies in our sample countries that recorded strong progress in innovation performance, especially in the last three years (Figure 2). Nevertheless, there is no room for complacency. Innovation capacity in Indonesia mostly has not been based on original research nor domestic in-house innovation due to Indonesia's relatively weak human capital (Figure 3). Accordingly, there are two options that Indonesia can opt for in the future. The first option is to follow China's and India's path where innovation is mostly done through imitation. The second option is to follow Malaysia's path where original innovative activities flourish. The first option may provide instant benefits in the short and medium run. However, it seems that the second option may deliver more promising economic and social returns in the future.

\subsection{The Development of Local Regula- tory Quality in Indonesia}

Having implemented a big-bang decentralisation system since 2001 by the enactment of Law Number 22 and 25 in 1999 on Administration and Financial Decentralisation, district governments in Indonesia have received significant authority to enact local regulations based on local needs (Butt 2010).
Those laws have mandated district authorities to perform various administrative functions with such low local own revenues. Consequently, this condition leads district governments to charge high local user charges and levies to fill the gap of their fiscal capacity critical to perform delegated service deliveries. On the other hand, businesses have submitted complaints about burdensome local taxes and user-charges set by district government. Moreover, local governments tend to accumulate local revenues rather than boost economic activity through business-friendly regulations. Thus, it discourages potential investors who want to keep distance from illegal and excessive charges or levies (Brodjonegoro 2004).

Quality of local regulations in a decentralised system has become important as an indicator of local government's policy framework to develop local economic activity. Complicated and confusing local regulations are obstacles to local businesses as these lead to uncertainties and restrict market access and trade (KPPOD 2011). The major regulatory problem in Indonesia's business activity is the overlapped functions of several business permits. For instance, trading permit has similar information as business registration (TDP) permits. However, both permits are required for different practical purposes such as SIUP which is for bank application and TDP for participation in government tender invitation ${ }^{1}$. These complicated regulations are intended for local revenue generation "without providing protection, control, or associated administration services, and often without fully analysing the impact of a license on firm behaviour" (Asia Foundation 2007). A study by KPPOD (2005) also highlighted the corruption of government and lack of transparency as major problems for businesses of all size. Businesses evaluated that there was lack of transparency on tendering process and lack of fairness in decision making related to business activity. LPEM-FEUI (2007) reported that $41 \%$ of respondents had to conduct face-to-face meetings with Provincial Ministry of Justice following more delegation of authority to Kanwil ${ }^{2}$ at the provincial

\footnotetext{
${ }^{1}$ SIUP (Surat ljin Usaha Perdagangan) is trade permit that is intended for trading company. TDP (Tanda Daftar Perusahaan) is company registration card.

${ }^{2}$ Since Indonesian decentralisation system kicked off, some functions of national offices have been delegated to offices at the provincial level in a sub-coordinated structure, not as an independent local body (Kanwil).
} 
level.

The absence of national regulation on closed list of local user charges and taxes encourages local governments to enact regulations that distort business activity. However, according to KPPOD, in 2005 local regulations had been more accommodative to business activity considering that $30 \%$ of local regulations could potentially distort business activity in 2001. The proportion of acceptable local regulations in 2004 was $58 \%$. In 2005, it rose to $83 \%$ for clarity of fees and $78 \%$ for clarity of procedure. Local regulations that were detrimental to business activity had also declined, from $12 \%$ of regulations in 2004 to only $10 \%$ in 2005 . The misuse of such great authority to charge taxes and user charges urged the national government to launch the revision of Law No. 34/2000 on local taxes and user charges. The positive list of regional taxes and user charges (Law No. 28/2009) may reduce the national government's burden in reviewing local regulations. This law also mandated the decentralisation of levies to district level, which was previously under the authority of central government

Local regulation quality in Indonesia has been evaluated annually by KPPOD since 2001 when the decentralisation system began. The KPPOD's index of local regulation quality is composed of 14 variables: (i) relevance of legal references, (ii) up-to-date legal references in use, (iii) legal completeness, (iv) disconnection of objective and substance, (v) clarity of objects, (vi) clarity of subjects, (vii) clarity of rights and obligations of fee payers and local governments, (viii) clarity of standards on time, costs, and procedures, or rate structure and standards, (ix) conformity between philosophy and principles of levies, $(x)$ national economic integrity and the principle of free internal trade, (xi) healthy competition, (xii) negative economic impact, (xiii) obstacles to public access and public interest (e.g., environment), and (xiv) violations of governmental authority. Variable 1-3 are grouped in legality subcomponent, variable 4-9 are grouped in substance sub-component, and variable 10-14 are grouped in principle sub-component. Judicial problems receive the lowest weight (15\%) since the impact of legality issues on businesses is less likely to be bigger than the economic impact of principle and substance sub-components. Substance and principle sub-components have bigger weights: $35 \%$ and $50 \%$, respectively.
Since the econometric analyses of this paper used the 2007 index published by KPPOD (2007), it is fruitful to probe a little deeper on the details of the 2007 quality of local regulations index The quality of local regulations index analysed local regulations mostly pertaining to licenses and permits. In total, there were 932 local regulations assessed in 2007 (Figure 4).

KPPOD (2007) reported that among the 14 variables of the local regulation index, the top three nuisances came from the following variables:

- Clarity of time, procedures, and costs of bureaucratic paperworks, e.g., licensing process (approximately $70 \%$ of local regulations in the sample had obscurity in this matter).

- Relevance of judicial references, e.g., local regulations did not refer to laws or higher regulations (approximately $32 \%$ of local regulations in the sample had this problem).

- Coherence in philosophy and principle of taxes and other non-tax retributions, e.g., local regulations related to local taxes and non-tax retributions did not adhere to the general classification of retribution stipulated by the higher law (approximately $28 \%$ of local regulations in the sample had this issue).

KPPOD (2011) found that around $39 \%$ of local regulations still contained problems of substance. The major problem of 245 reviewed districts was mainly on the lack of clarity of business procedures, time standards, and rates of charges; the second problem was lack of clarity of rights and obligations of fee payers. However, the 2011 index had shown an improvement in regulatory quality compared with 2007 when the major problem of clarity of business procedure was still about $70 \%$ of the reviewed local regulations of 243 districts.

Above all, Indonesia has made progressive business reforms at the local level as argued in the study of Sub-National Doing Business Report in Indonesia (World Bank \& International Finance Corporation 2012). It showed that the average time to start a business and deal with construction permits had been reduced by more than $25 \%$ since 2010 . Hence, it was 13 days faster and $8 \%$ cheaper to do business in the major fourteen cities in Indonesia in 2012 than in 2010. Such reform occured due to the simplification of local licensing requirements, establishment of one-stop shop, introduction of statutory time limits, and elimination of or reduction in 


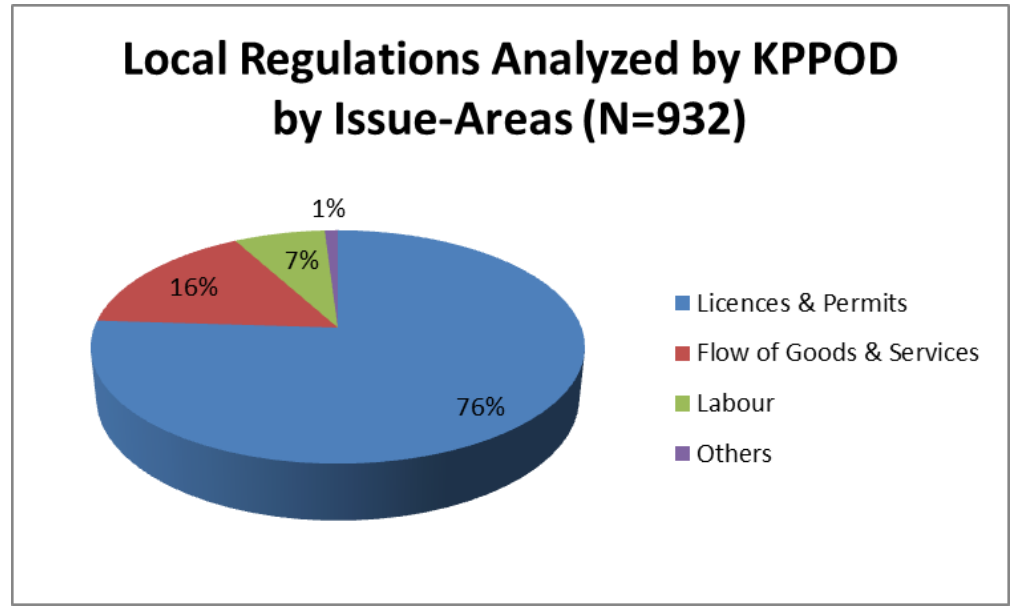

Figure 4: Quality of Local Regulations Index: Distribution of Issue Areas of Regulations Source: KPPOD (2007)

fees for local licenses since 2010. Such reform represented some improvement of business-friendly regulation enactment at the local level.

\subsection{Access to Finance in Indonesia: A Comparative View}

This section discusses the state of access to finance in Indonesia. We focused on the recent development of financing to the private sector in Indonesia. Similar to Section 3, our strategy was by comparing Indonesia with comparable countries. We chose three major developing Southeast Asian countries: Malaysia, Thailand, and Philippines; as well as two developing Asian economic powerhouses: China and India to see how Indonesia fares in comparison.

There are two main dimensions that relate to access to finance which we looked into. The first dimension is the interest rate. This dimension is important to look at since interest rate is, in principle, the 'price' of borrowing. Higher interest rates indicate that lenders such as financial institutions view lending activities as riskier. We focused on the lending rate indicator as it is the most relevant interest rate measure related to financial intermediation. The second dimension is institutional infrastructure. More specifically, we were interested to see how information and legal infrastructure in the financial sector that facilitate lending are related to the function of financial intermediation by financial institutions, i.e., banks.

The first exhibit is to compare Indonesia's lending rate with our select countries. Cross-country comparison of lending rates is not a straightforward exercise. Each country may have its own terms and conditions attached to the rates, thus cross-national comparability is limited. However, we can compare the trend and pattern of lending rate across countries over the time. As such, we set 2003 as our base year and standardised the lending rate for each country to 100 . Figure 5 shows that Indonesia has experienced a decline in its lending rate relative to others. As expected, China topped the list since this may reflect the direction of China to prevent its overheating in recent period. On the other hand, together with the Philippines, Indonesia as of 2011 bottomed the list. This gives the hint that the 'price' for borrowing in Indonesia had decreased substantially between 2003 and 2011. Likewise, this condition is likely to provide the space necessary to promote more lending activities by financial institutions in Indonesia.

However, merely looking into lending rate does not provide us with an accurate state of the costs of borrowing. In order to take macroeconomic stability such as inflation rate into account, we used real lending rate for the second exercise. This indicator shows the real costs of borrowing. As shown in Figure 6, China and Malaysia had the lowest real lending rate with each country experiencing less than $2 \%$ average real lending rate. Between 2003 


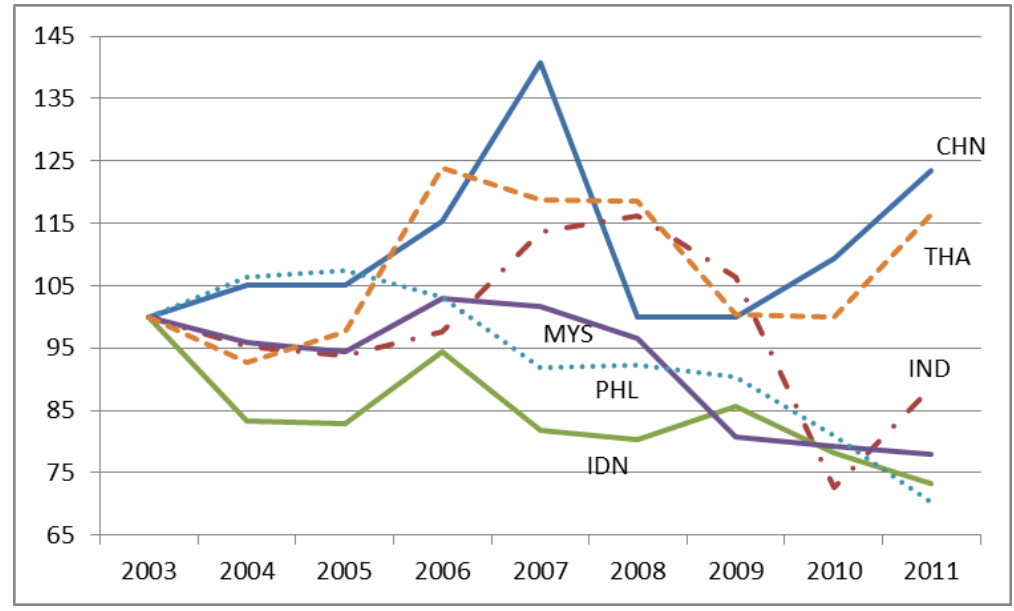

Figure 5: Lending Rate $(2003=100)$

Source: World Bank

and 2011 , the average real lending rate in Indonesia was $3.34 \%$. This indicates that the real cost of borrowing in Indonesia was quite competitive in comparison with other major Asian countries.

The last exercise with the interest rate dimension is to look into interest rate spread. We defined interest rate spread as nominal lending rate minus the deposit rate. In principle, this indicator is used to see how financial institutions, i.e., banks, place the 'premium' on their lending activities. The wider the spread is, the larger the premium will be. If banks perceive larger risk in giving out lending, the premium will be larger. Figure 7 shows that Malaysia and the Philippines had experienced a sharp decline in interest rate spread in 2009-2011. In contrast, Indonesia experienced a staggering level of interest rate spread during 2007-2011.

When making decisions on loans, banks are concerned with two factors: (i) the interest rate received on the loan, and (ii) the riskiness of the loan (Stiglitz \& Weiss 1981). As Figure 5 shows, the lending rate in Indonesia, in general, has been in a declining trend. However, for developing countries, barriers in access to finance are likely to root in transaction costs due to informational asymmetries such as adverse selection. Mahendra (2009) argued that domestic financing in Indonesia has been sub-optimal due to financial frictions in the credit market. These frictions have led to higher premium charged by banks in Indonesia. Figure 7 confirms Mahendra (2009) by showing that the interest rate spread between 2007 and 2011 for
Indonesia had been staggering. This reflects a lingering relative high 'price' in taking loans in Indonesia. As a consequence, this friction in the credit market may act as an impediment in financial intermediation in Indonesia.

So far, we have seen that the costs of borrowing in Indonesia were staggering, even compared with other strongly growing Asian economies. The next question is what may explain this phenomenon. We turned to our second dimension: institutional infrastructure. We relied on two financial infrastructure indicators developed by the World Bank for the analysis. The first indicator is strength of legal rights index. This indicator measures "the degree to which collateral and bankruptcy laws protect the rights of borrowers and lenders and thus facilitate lending"3. This index ranges from 1 to 10 where higher scores indicate better laws that facilitate lending activities.

The second indicator is credit depth of information index. This indicator measures "the rules affecting the scope, accessibility, and quality of credit information available through public or private credit registries"4. This index ranges from 0 to 6 . Higher scores indicate that more credit information are available that helps banks in making lending decisions, thus facilitating lending activities. These two indices are institutional infrastructure that may

\footnotetext{
${ }^{3}$ http: //data. worldbank . org/indicator/IC . LGL . CRED . $\mathrm{XQ}$ ?page $=1$.

${ }^{4}$ http: //data.worldbank.org/indicator/IC. CRD. INFO. $X Q$ ?page $=1$.
} 


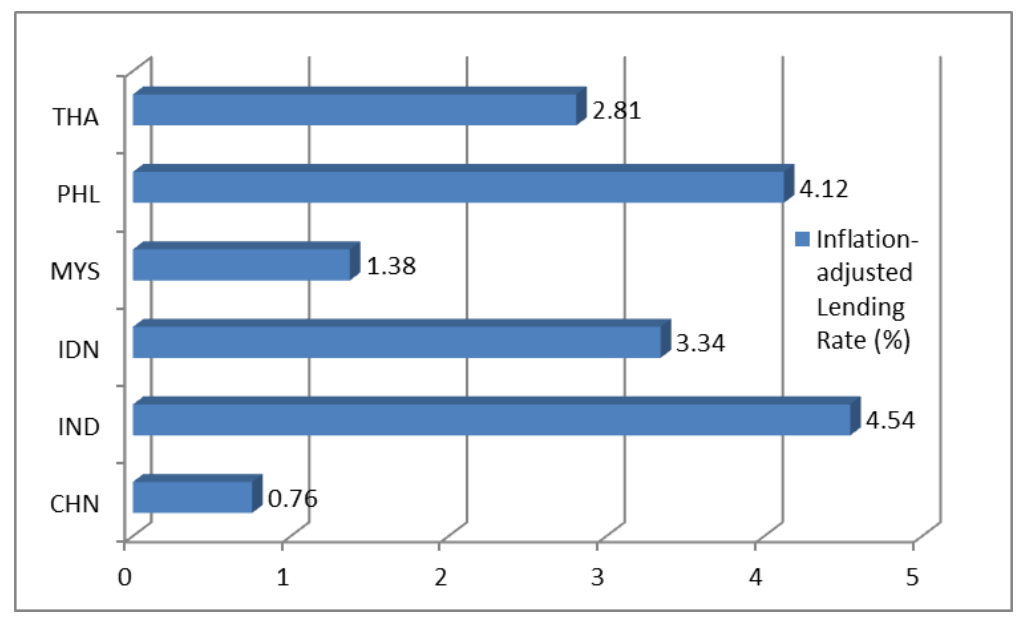

Figure 6: Real Lending Rate (average, 2003-2011) Source: World Bank

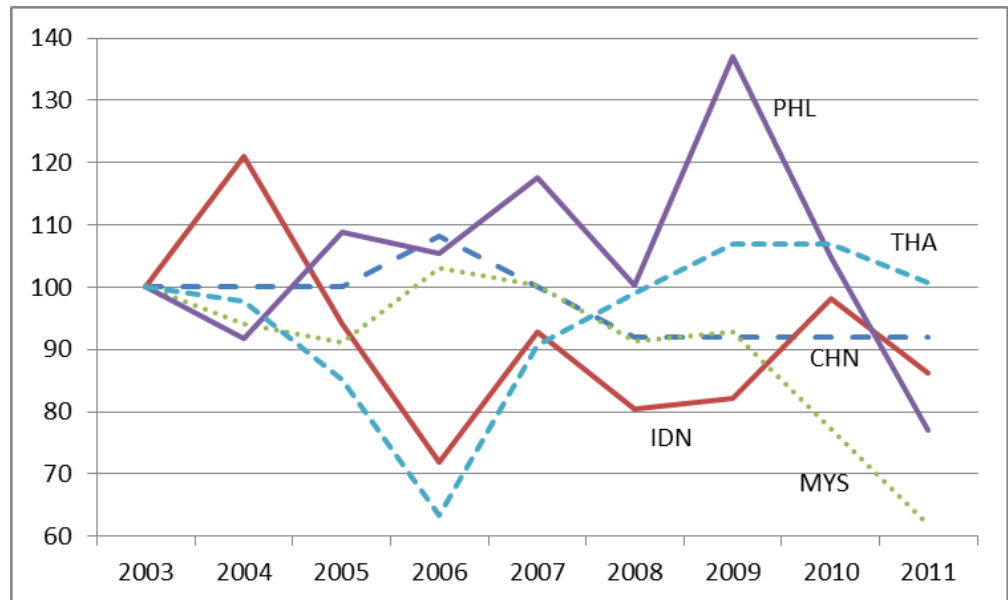

Figure 7: Interest Rate Spread (2003=100)

Source: World Bank 
help to lessen financial frictions in the credit market. Higher scores in these indices mean that the country has the necessary tools to reduce information asymmetries in the credit markets. As a consequence, we can expect that strong legal rights index as well as high credit depth of information index are associated with more credits flowing to the real sector.

Figure 8 shows that the two indices were associated with the size of credits flowing to the real sector. Certainly, there are many factors that explain the size of credits in a country's economy. It is possible that a country has low scores on these indices but still records a large credit share to GDP. This might be due to directed (government-facilitated) lending or interest rate subsidies directed to specific groups in the economy or even over-reliance on external (foreign) financing. Either way, better institutional infrastructure in the financial sector should provide the necessary ground for credit expansion.

As shown in Figure 8, in 2004-2011, Indonesia was lagging behind in domestic credit provided by the banking sector (the size of the bubble). Even the Philippines had slightly higher domestic credit to GDP $(49.38 \%$ compared with only $40.83 \%$ for Indonesia). In general, countries with higher scores in institutional infrastructure indices tended to have larger amount of credit provided by their banks. Indonesia had the lowest average score of the two indices. On the other hand, Malaysia was the prime example of success in our exercise. Having strong institutional infrastructure in their financial sector has provided Malaysia with the necessary platform to support the flow of credit to their private sector.

This section shows that Indonesia has not been well positioned compared with other major emerging Asian countries in access to finance. We show that the costs of borrowing in Indonesia were relatively staggering in the region amidst declining nominal lending rate. This reflects the lingering frictions in the Indonesian financial markets due to asymmetric information problem. Such obstacle has been rooted in the lack of quality in institutional infrastructure in the financial sector as displayed by weak legal rights and limited credit information. Compared with other countries in our sample, Indonesia ranked last in institutional infrastructure in the financial sector. These problems have led to sub-optimal domestic financing in Indonesia which manifests in a comparatively low credit penetration to the real sector of the economy.

\section{Method}

To answer our research questions, we opted for firm-level data analysis utilising the World Bank Enterprise Surveys (WBES) micro dataset. The survey for Indonesia was conducted between August 2009 and January 2010 and focused on capturing various factors that shape and influence business environment. The surveys asked business owners and top managers detailed questions regarding their establishments as well as their perceptions on business climate faced by the establishments. The surveys targeted manufacturing and services industries. Unfortunately, for Indonesia the WBES have only been conducted once in 2009. Thus, the WBES micro data for Indonesia are basically cross-sectional, limiting our ability to exploit the richness of information from a panel data setup. The survey for Indonesia was able to cover 1,444 firms with most firms classified as small- and medium-sized enterprises (SMEs). Using a stratified random sampling strategy, the 2009 Indonesia WBES gathered firm level data for 9 provinces with more than half located in Java.

To analyse the role of institutions, we used the 2007 Local Economic Governance Surveys conducted by the Indonesia's Regional Autonomy Watch (KPPOD). The survey was conducted at the district level, covering 243 districts from 15 provinces. Similar to WBES, the KPPOD survey sample was also skewed towards SMEs. We matched the WBES and KPPOD surveys data by provinces. Our matched data ended up with only six provinces: Bali, Jawa Barat, Jawa Tengah, Jawa Timur, Sumatera Utara, and Sulawesi Selatan. In other words, 3 other provinces of the WBES surveys (Banten, Lampung, and DKI Jakarta) had to be dropped. Ideally, the matching procedure should be done at the district level since KPPOD data were produced at this level. However, the WBES firm identifier is only at the province level. Another option was to use the original firm survey of KPPOD. Unfortunately, the KPPOD surveys' questionnaires did not ask about firm's innovative activities, hence it was not workable for our analysis. Finally, since services industry might 


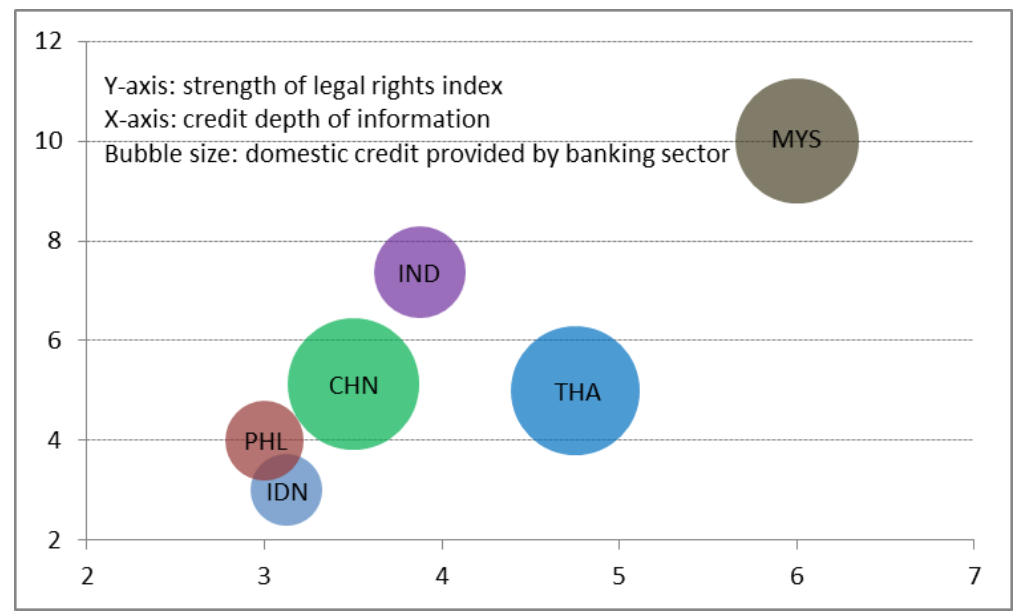

Figure 8: Institutional Infrastructure and Domestic Credit (average, 2004-2011) Source: World Bank

have different innovation pattern and determinants, we decided to limit our analysis only for manufacturing firms. This decision was further supported by the fact that one of our dependent variables, patent registration, is more relevant for manufacturing firms.

Archibugi \& Pianta (1996) argued that patents and innovation surveys are good proxies for firm's technological activities. Meanwhile, Kleinknecht, Van Montford \& Brouwer (2002) surveyed the strengths and weaknesses of five different measures of innovative activities. They showed that R\&D and patents (two of the most commonly used indicators) are not necessarily the best indicators to measure innovation activities, and advised researchers to use innovation indicator that suits the research question and level of analysis. Accordingly, we decide to apply a more flexible strategy in measuring innovation activities. Our dependent variables are (i) a broad measure of innovation and (ii) a proxy for product innovation. Several empirical studies on innovation have adopted the broad and flexible measuring strategy. Bartel, Ichniowski \& Shaw (2007) used the count of computer numerically controlled (CNC) machines owned by firms in valve manufacturing industry as a measure of innovation. Meanwhile, Bloom \& Van Reenen (2007) developed an innovative survey to measure innovation management practices. Mairesse \& Mohnen (2010) provided the definitive survey on various innovation indicators applicable for empirical analysis.
Such strategy is likely to be more appropriate for developing countries as opposed to other traditional measures of innovation such as R\&D expenditures (Gorodnichenko, Svejnar \& Terrell 2010). Moroever, since the economies of developing countries and in fact our sample are mostly composed of SMEs, traditional innovation measures may not capture appropriately the innovation activities of SMEs (Hoffman et al. 1998). Developing countries indeed have different types of innovation as opposed to developed countries wherein for developing countries innovation is mostly conducted not at the technological frontier and is a mixed-baggage of original innovation as well as adoption and imitation of various types of product and process innovation (Segerstrom 1991; Ayyagari, Demirguc-Kunt \& Maksimovic 2011).

Our approach in constructing a broad measure of innovation is inspired by Lall (1992) who proposed a broad index to measure firm technological capabilities. In this paper, we tried to capture both product innovation and process innovation in a single index. Given the limited scope of innovative activities included in the 2009 Indonesia WBES, we only used 3 indicators: product innovation (patents) and process innovation (ISO certification and licensed foreign technology).

For the empirical analysis, we basically ran two separate groups of regressions. One group of regressions has product innovation (patents) as its dependent variable. Since the patent variable is binary, we employed logit regressions with the fol- 
lowing specification

$$
\text { Patents }_{i j p}= \begin{cases}1, & \text { if } \pi_{i j p}^{*}>0 \\ 0, & \text { if } \pi_{i j p}^{*} \leqslant 0\end{cases}
$$

Here we assumed that a firm follows a profitmaximising strategy in which it will engage in product innovation (registering for patents) if the benefits exceed the cost. Thus, a firm $i$ in industry $j$ in province $p$ will have a registered patent if the economic profit $\pi^{*}$ is positive. Hence, Patents $s_{i j p}$ is a binary variable that equals one if a firm has at least one registered patent in any country. We further assumed that $\pi^{*}$ is a function of firm, industry, and province characteristics and that it is not directly observable so that:

$$
\pi_{i j p}^{*}=\beta X_{i j p}+A c c_{-} \text {Fin }_{i j p}+\operatorname{Reg}_{p}+\lambda_{j}+\varepsilon_{i j p}
$$

Therefore, we can write the the probability of a firm to have at least one registered patent (product innovation) as follows:

$$
\begin{array}{r}
\operatorname{Pr}\left(\text { Patent }_{i j p}=1\right)=\operatorname{Pr}\left(\text { Acc_Fin }_{i j p}+\text { Reg }_{p}\right. \\
\left.+\beta X_{i j p}+\lambda_{j}+\varepsilon_{i j p}>0\right)
\end{array}
$$

where $X_{i j p}$ is a vector of firm characteristics (control variables), $\lambda_{j}$ is industry fixed-effects, and $\varepsilon_{i j p}$ is unobserved firm, industry, and province characteristics. Access to finance $\left(A c c_{-}\right.$Fin $\left._{i j p}\right)$ and quality of local regulations $\left(\operatorname{Reg}_{p}\right)$ are our variables of interest. We assume that $\varepsilon_{i j p}$ is logistically distributed, so that we employed logit regressions. Detailed description of the variables, their sources, and summary statistics are displayed in Figure 13.

Our second dependent variable is innovation index that measures firm innovative activities. We adopted a broad measure approach of technological capabilities index theoretically developed by Lall (1992) and implemented by Wignaraja (2002). However, given the limited set of questions on firm's innovative activities in our data set, we did not follow the normalisation procedure and opted instead for a simple counting procedure. In addition to patent, we incorporated a measure of whether a firm has an internationaly-recognised quality certification (ISO) and if a firm uses technology licensed from a foreign-owned company excluding office software (foreign technology). These two additional measures are also binary variables that equal to one if a firm has each of the measure.
We then construct an innovation index by adding up each innovative activities. Thus, our innovation index ranges between 0 (no innovation) and 3 (all three innovative activities). Accordingly, we can regard the innovation index as an ordinal variable in which higher scores indicate more expansive innovative activities and estimated ordered logit regressions where for an $m$-alternative ordered model, we defined:

$$
\begin{gathered}
\pi_{i j p}=z \text { if } \alpha_{z-1}<\pi_{i j p}^{*} \leqslant \alpha_{z}, z=1, \ldots, m \\
\text { Innov_Index } x_{i j p}= \begin{cases}m, & \text { if } \pi_{i j p}^{*}>\alpha_{z} \\
1, & \text { if } 0<\pi_{i j p}^{*} \leqslant \alpha_{z} \\
0, & \text { if } \pi_{i j p}^{*} \leqslant 0\end{cases}
\end{gathered}
$$

where $m$, the maximum alternative, in our case is 3 (firm is engaged in all three types of innovative activities). We also assumed that a firm follows profitmaximising behaviour in which firm chooses to engage in more expansive innovative activities if it sees larger economic profits in doing so. Thus, we can write the probability of a firm to engage in innovative activities (innovation index) as the following:

$$
\begin{array}{r}
\operatorname{Pr}\left(\text { Innov_Index } x_{i j p}=z\right)=\operatorname{Pr}\left(\alpha_{z-1}<A c A_{-} \text {Fin }_{i j p}\right. \\
\left.+\operatorname{Reg}_{p}+\beta X_{i j p}+\lambda_{j}+\varepsilon_{i j p} \leqslant \alpha_{z}\right)
\end{array}
$$

We also assumed that $\varepsilon_{i j p}$ has logistic distribution and ran ordered logit models. We employed the same set of regressors with the product innovation regressions.

For the innovation index analysis, we also considered alternative specifications. Recall that our innovation index was constructed via simple counting procedure, hence it is plausible to regard the variable as a count data since our dependent variable is basically a count of firm innovative activities. Therefore, we extended our analysis by running Poisson regressions to enrich our inferences as well as robustness checks. Finally, we estimated different regressions for firms differentiated by sample: small and medium enterprises (SMEs) vs large firms. SMEs and large firms may have different pattern of their innovation determinants; in our case, they are institutions and access to finance (Acs \& Audretsch, 1988).

One challenge for our analysis was to infer causality running from our variables of interest (access to 
finance and quality of local regulations) to innovation. There were two sources of issues that might limit our capacity to address causality. The first is reverse causality. This problem is less pronounced for quality of local regulations. We can confidently say that it is very unlikely that firm's innovative activities can affect the quality of local regulations. In fact, this index was constructed based on legal analysis which strengthens its exogeneity. On the other hand, it is possible that innovative activities influence firm's access to finance. If a firm's innovative activities are run inefficiently, it may lead the firm to face problems in securing external financing. The second issue is even more important: omitted variable bias. It is likely that there are unobserved factors that affect both our dependent variables (innovation measures) and main explanatory variables (access to finance and quality of local regulations).

The first-best strategy to tackle the causality problem was to find an instrument-especially for access to finance variable. However, we were unable to find convincing instrument for access to finance that is not correlated with the error term. The problem was magnified by the fact that our data is cross-section. This limits the space to address any endogeneity issue that would otherwise have been provided if we had had a panel data setup by controlling for any time-invariant factors and unobservables or by employing dynamic panel analyses. Therefore, we followed the second-best approach. First, we introduced a variable that controls for a firm's initial condition (initial size). In addition, we also controlled for firm's characteristics (age, human capital, and foreign ownership) that may correlate with access to finance. Finally, we also incorporated industry fixed effects to control for any unobserved factors at the industry level.

Although it is not ideal, by controlling for firm's initial condition, firm's idiosyncratic characteristics, and industry fixed effects, it may moderate the endogeneity issue for access to finance. As for quality of local regulations, we believe that the endogeneity problem is much less pronounced. As shown by Almeida \& Fernandes (2008) who analysed the effect of openness on technological innovations in developing countries, we could still derive robust estimates even if the data setup is cross-section by nature. In the same vein, Ayyagari, DemirgucKunt \& Maksimovic (2011) also argued that crosssectional analysis can still provide useful explana- tions on the linkages between innovation determinants and innovative activities. We believe that our novel approach focusing on local institutions and access to finance may at least give useful insights for policymakers on the important role of local regulatory quality and access to finance in spurring innovation.

\section{Results and Analysis}

Before we discuss the results of our empirical analyses, we shall start with a brief look into the general characteristics of our data. We had two dependent variables: (i) registered patents as a measure of product innovation and (ii) an innovation index as a measure of innovative activities. Since product innovation is one of the foci in this paper, we thus excluded firms in the services and trade industries. In this paper, we only analysed firms in manufacturing. Our full sample was comprised of 856 firms distributed over 7 different sectors in manufacturing (Figure 9). Over $30 \%$ of the firms were in food industry and for other sectors, the distribution was quite well-balanced.

Regarding the location of the firms, they were mostly located in Java (>80\%). Jawa Barat is where the majority the firms were located $(30.02 \%)$, followed by Jawa Tengah and Jawa Timur with $25.82 \%$ and $25.12 \%$, respectively. We had 3 non-Java provinces in our sample: Bali, Sulawesi Selatan, and Sumatera Utara.

On the distribution of the quality of local regulations index, the three provinces in Java also topped the table with Jawa Timur came out on top as the province with the highest score in quality of local regulations index (86.32). Jawa Tengah and Jawa Barat followed suit with 85.77 and 85.20 , respectively. Bali turned out to be the province with the worst score on the quality of local regulations index (80.97). This makes the difference between the best performing province (Jawa Timur) and the worst performing province (Bali) only 5.35 points. The other two non-Java provinces came next with 84.23 (Sulawesi Selatan) and 83.10 (Sumatera Utara). The stark difference on the quality of local regulations index between Java and nonJava provinces may reflect the discrepancy of institutional quality among these regions. At least in our sample, we found that provinces in Java had 


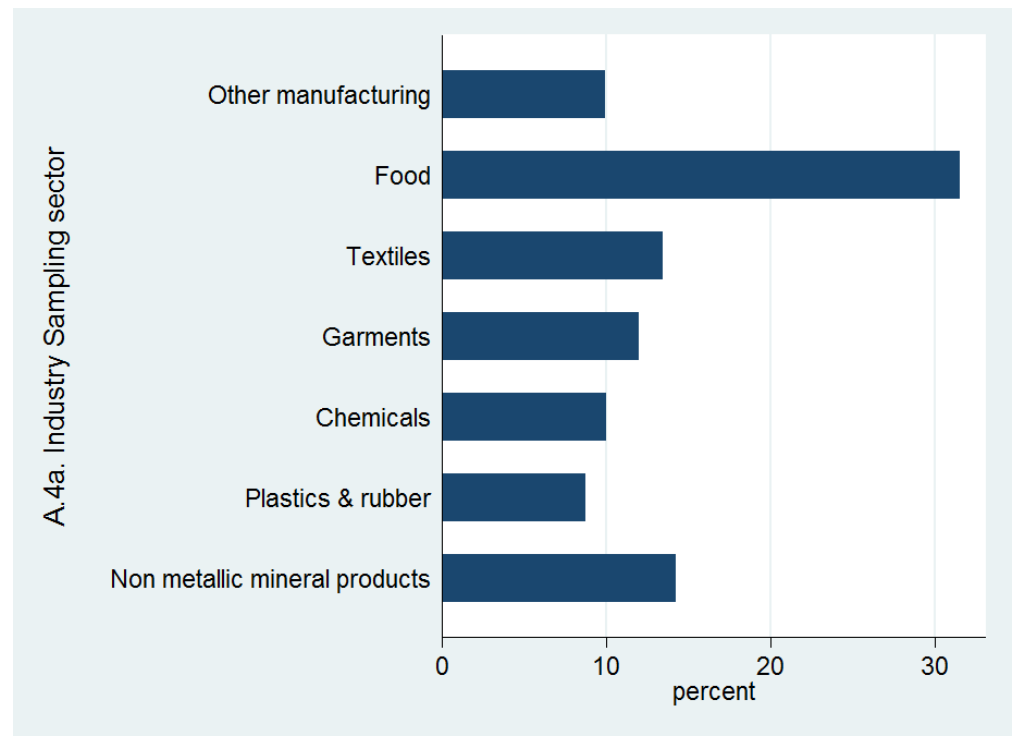

Figure 9: Firm Distribution by Industry Source: Author's calculation

relatively better institutional quality than non-Java ones. Table 1 displays the scores of the quality of local regulations index for each province as well as the distribution of firms by province.

Literature has shown that human capital matters for innovation. Therefore, firms with better human capital are more likely to engage in innovative activities. Our sample supported this claim. Figure 10 shows that firms with higher skills (both managers and workers are more skilled) were more likely to be involved in innovative activities. Similar pattern was also apparent in product innovation. Firms with educated managers and workers also tended to have more registered patents (Figure 11). These findings were evident across provinces, and that such gap due to differences in firm's human capital was starker in provinces located in Java.

Finally, as discussed in the literature review, the theory also states that firm size matters for access to finance. Larger firms are more likely to acquire external financing than the smaller ones. Smaller firms may lack the collateral or quality credit information necessary to obtain loans from commercial banks. Moreover, larger firms may have the capacity to raise external funds not only from banks (credit markets), but also from financial markets such as the capital or bond markets. Certainly, larger firms can also have difficulties in securing external finance, especially when they are overtly leveraged or lack quality governance. Nevertheless, under normal condition, we can expect to find more smaller firms face obstacles in access to finance than larger firms. In Table 2, we do a crosstabulation between firm size and access to finance. We found that only $15 \%$ of large firms reported access to finance as major obstacle. In contrast, 55\% of small firms mentioned access to finance as their major obstacle. As we can see, the proportion of firms reporting access to finance as major obstacle grew by firm size. In total, we had $41 \%$ firms facing major obstacle in access to finance-thus providing a relatively well-balanced sample for our econometric analyses.

In the subsequent sub-sections, we discuss the results of our econometric analyses. We started with the product innovation regressions. Then, we moved on to innovation index regressions with ordered logit model. Accordingly, we also provided alternative estimates for the innovation index with Poisson regressions. Following that, we performed separate regressions for SMEs and large firms to see how access to finance and quality of local institutions may have different influences within each group. Finally, we discussed the adjusted predictions from access to finance and quality of local regulations index controlling for other variables as well as their interaction term. 
Table 1: List of Provinces, Sample of Firms, and Quality of Local Regulations Index

\begin{tabular}{lrrc}
\hline Province & Firm Sample (N) & Firm Sample (\% of total) & $\begin{array}{c}\text { Quality of Local Regulations Index } \\
\text { (averages of regencies and districts) }\end{array}$ \\
\hline Bali & 50 & 5.84 & 80.97 \\
Jawa Barat & 257 & 30.02 & 85.20 \\
Jawa Tengah & 221 & 25.82 & 85.77 \\
Jawa Timur & 215 & 25.12 & 86.32 \\
Sulawesi Selatan & 55 & 6.43 & 84.23 \\
Sumatera Utara & 58 & 6.78 & 83.10 \\
\hline
\end{tabular}

Source: Author's calculation

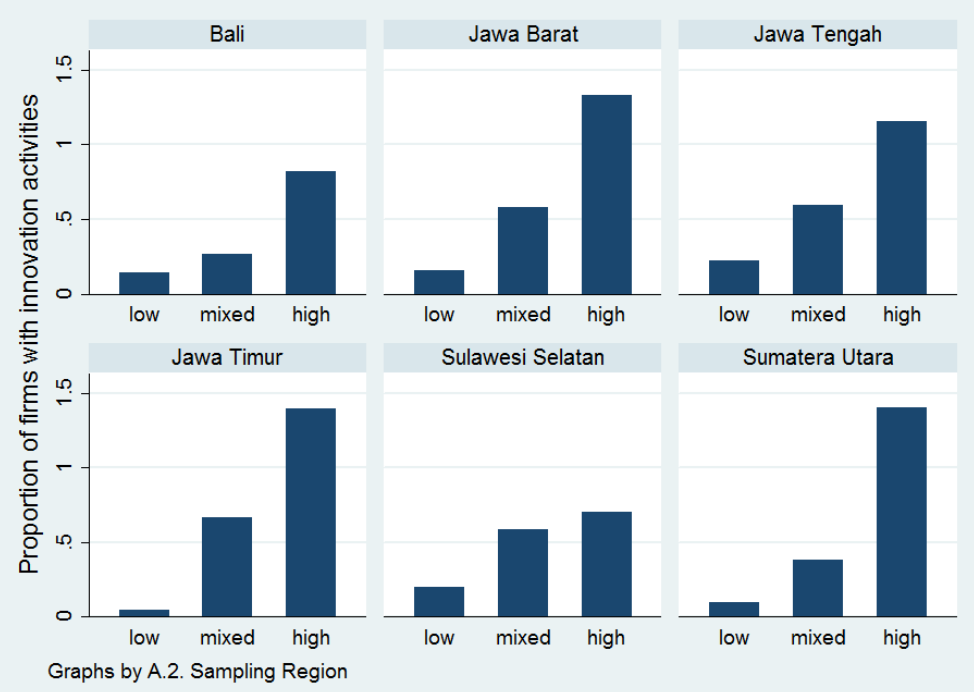

Figure 10: Innovation Index and Firm Human Capital Source: Author's calculation

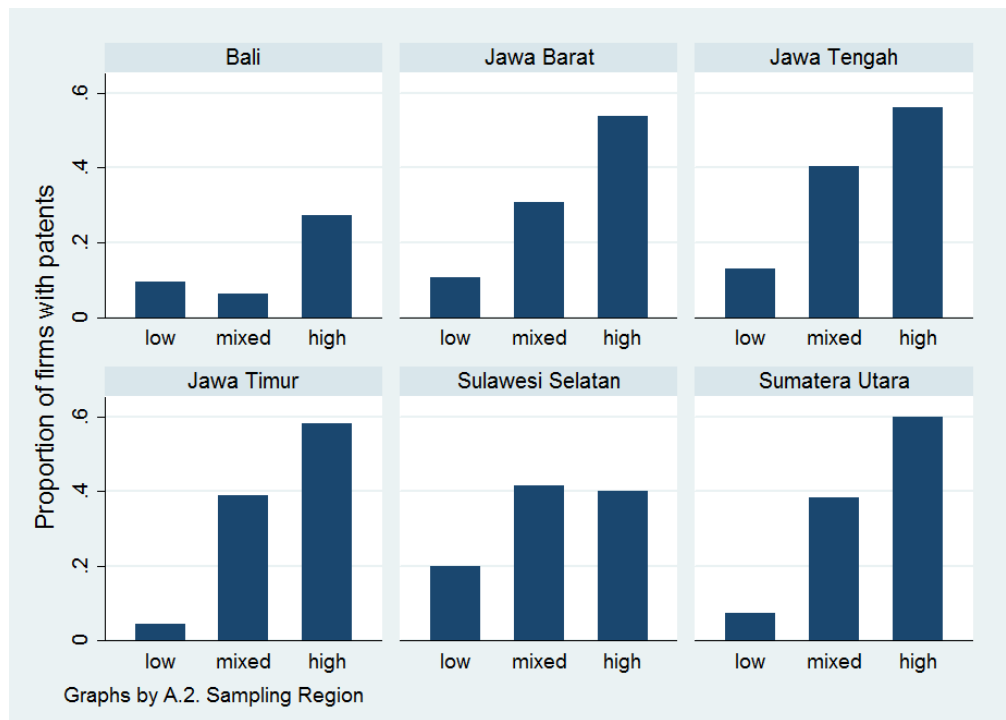

Figure 11: Product Innovation and Firm's Human Capital Source: Author's calculation

Economics and Finance in Indonesia Vol. 61 No. 3, December 2015 
Table 2: Cross Tabulation: Firm's Size \& Access to Finance

\begin{tabular}{lccc}
\hline \multirow{2}{*}{ Province } & \multicolumn{2}{c}{ Access to Finance is } & \multirow{2}{*}{ Total } \\
\cline { 2 - 3 } & No Major Obstacle & Major Obstacle & \\
\hline \hline Small (5-19) & 170 & 208 & 378 \\
$\quad$ Frequency & $45 \%$ & $55 \%$ & $100 \%$ \\
$\quad$ Row Percentage & & & \\
\hline Medium (20-99) & 129 & 77 & 206 \\
$\quad$ Frequency & $63 \%$ & $37 \%$ & $100 \%$ \\
$\quad$ Row Percentage & & & \\
\cline { 3 - 4 } Large (>99) & 150 & 26 & 176 \\
$\quad$ Frequency & $85 \%$ & $15 \%$ & $100 \%$ \\
$\quad$ Row Percentage & & & \\
\hline \hline Total & 449 & 311 & 760 \\
$\quad$ Frequency & $59 \%$ & $41 \%$ & $100 \%$ \\
$\quad$ Row Percentage & & & \\
\hline Source: Author's calculation & & &
\end{tabular}

\subsection{Product Innovation Estimates}

In this sub-section, we discuss the regression results for product innovation. That said, we used patent registration as a proxy for product innovation. Our dependent variable was thus a binary data which equals to 1 if a firm owns at least one patent registered in any country, and 0 if otherwise. Therefore, we opted for a binary logit model. Table 3 displays the results. We performed four separate regressions with different modification for each estimate. For every regression, we controlled for several firm characteristics, namely, firm size, firm age, firm human capital, and firm's foreign ownership level (for detailed description of variables, please refer to Figure 13). We also included a control for firm's initial condition (firm's initial size). We believe this was necessary given the cross-sectional nature of our data, we were not able to control for time-invariant firm's characteristics. However, following Almeida \& Fernandes (2008) and Ayyagari, Demirguc-Kunt \& Maksimovic (2011), such cross-sectional design would not necessarily reduce the message of the results and policy implications. In fact, we went further by also incorporating a measure of firm's initial size as an additional control variable. We also conducted estimates controlling for industry fixed effects for robustness checks. All regressions were estimated with robust standard errors.

In the baseline regressions, estimation (1) shows that quality of local regulations and access to finance influenced product innovation. We pre- sented our results in odd ratios to ease interpretation. We found that having access to finance as major obstacle reduced the probability for firm to have product innovation by $41 \%$. Meanwhile, better quality of local regulations was associated with $19 \%$ probability to have product innovation. All effects were significant at $5 \%$ level. Most control variables had the expected signs and significance levels. As we can see, larger firms were more likely to have product innovation. Likewise, older firms and better human capital owned by firms were associated with more likelihood to engage in product innovation. The results from estimation (1) confirm our hypotheses that obstacles in access to finance are negatively associated with innovation and that better quality of local regulations is associated with more product innovation.

In estimation (2), we introduced an interaction term of access to finance and quality of local regulation index. We centred the quality of local regulation index to ease interpretation since our empirical model was basically non-linear. Hence, our institutional quality indicator could be interpreted as a centred variable. In other words, we could interpret the results as the effect when quality of local regulations index fell below or went above the average score. Introduction of the interaction term did not change the individual effect of our main explanatory variables. We still found that having access to finance as major obstacle was associated with $40 \%$ less likelihood to have product innovation. Meanwhile, we also found that firms located in provinces with better institutional environment 
were associated with more product innovation. Interestingly, we found that the interaction term was significant. Given that our empirical model was non-linear, we could not directly interpret the magnitude of the interaction term from the odd ratio. However, we could say that the positive effect of better quality of local regulations was moderated by access to finance. More specifically, firms facing access to finance as major obstacle were disproportionately and negatively affected by better institutional quality. This result gives the hint that the positive impact of better local institutional quality is not symmetrically distributed. That is, firms with access to finance reap most of the benefits of better local institutional quality. We shall further explore this interesting finding later in this section.

Estimation (1) and (2) did not control for industryspecific characteristics. It was likely that different industry had idiosyncratic characteristics that might explain their product innovation. We introduced industry fixed effects in estimation (3) and (4). As we can see, the results did not change too much. The estimated effects and significance were robust.

\subsection{Innovative Activities Estimates}

In this sub-section, we present our analysis on how access to finance and quality of local regulations affect innovative activities. As we have discussed in Section 6, we constructed an innovation index to serve as a proxy for innovative activities. In principle, the index attempts to capture both product innovation and process innovation. Therefore, we aimed to capture a more comprehensive measure of firm's innovative activities. Registered patents remained as the indicator of product innovation. We introduced two measures to serve as a proxy for process innovation. The first is the use of internationally recognised quality certification such as ISO certificates. We coded 1 if a firm owned any and 0 if otherwise. The second measure is the use of technology licensed from a foreign-owned company, excluding office software. Similar to quality certification, we also coded 1 if the firm owned any foreign-licensed technology and 0 if otherwise. To construct the innovation index, we summed up these three indicators. We did not perform any standardisation since all indicators were binary. Hence, the lowest score was 0 , which means the firm did not engage in any innovation, while 3 was the highest score which means the firm had all three types of innovative activities. We conducted ordered logit regressions since the construction of our innovation index could be regarded as ordinal data.

Our regressions for innovation index followed the same strategy as product innovation regressions. We used the same control variables and also introduced industry fixed effects (Table 4) . Surprisingly, as displayed in estimation (5), we did not find any significant effect of access to finance and quality of regulations on innovative activities amidst expected signs. Other controls, however, remained significant. In fact, firm's initial size, which was not found to be significant in product innovation regressions, was now significant albeit its negligible effect. The presence of foreign ownership in a firm was also found to be significant. We found that firms with more than $10 \%$ foreign ownership were 3.43 times more likely to engage in innovative activities. Above all, these results from estimation (5) give the hint that quality of local regulations and access to finance are more important for innovation output (product innovation) but not necessarily critical for innovation input (process innovation).

Estimation (5), nonetheless, did not take into account the possibility that the effect of local regulations index only comes jointly with access to finance. Estimation (6) explored such possibility using the same strategy as estimation (2) in product innovation regressions. As we can see, we then found that quality of local regulations mattered for innovative activities. However, such effect was not independent-it came along with the interaction term. This finding further confirms the hypothesis that the positive effect of better institutional quality is asymmetrically distributed. Firms which face no obstacles in access to finance are much better off from improved local institutional quality.

Interestingly, we still did not find any significant impact of access to finance in estimation (6). Although the direction was still as expected, we could not reject the null hypothesis of significant effect. One possible explanation for this is that access to finance matters more for innovation output (product innovation). Our proxy for product innovation is registered patents. Such innovative activity is likely to be much costly to finance as opposed to process innovation (quality certificates or usage of foreign- 
Table 3: Determinants of Product Innovation

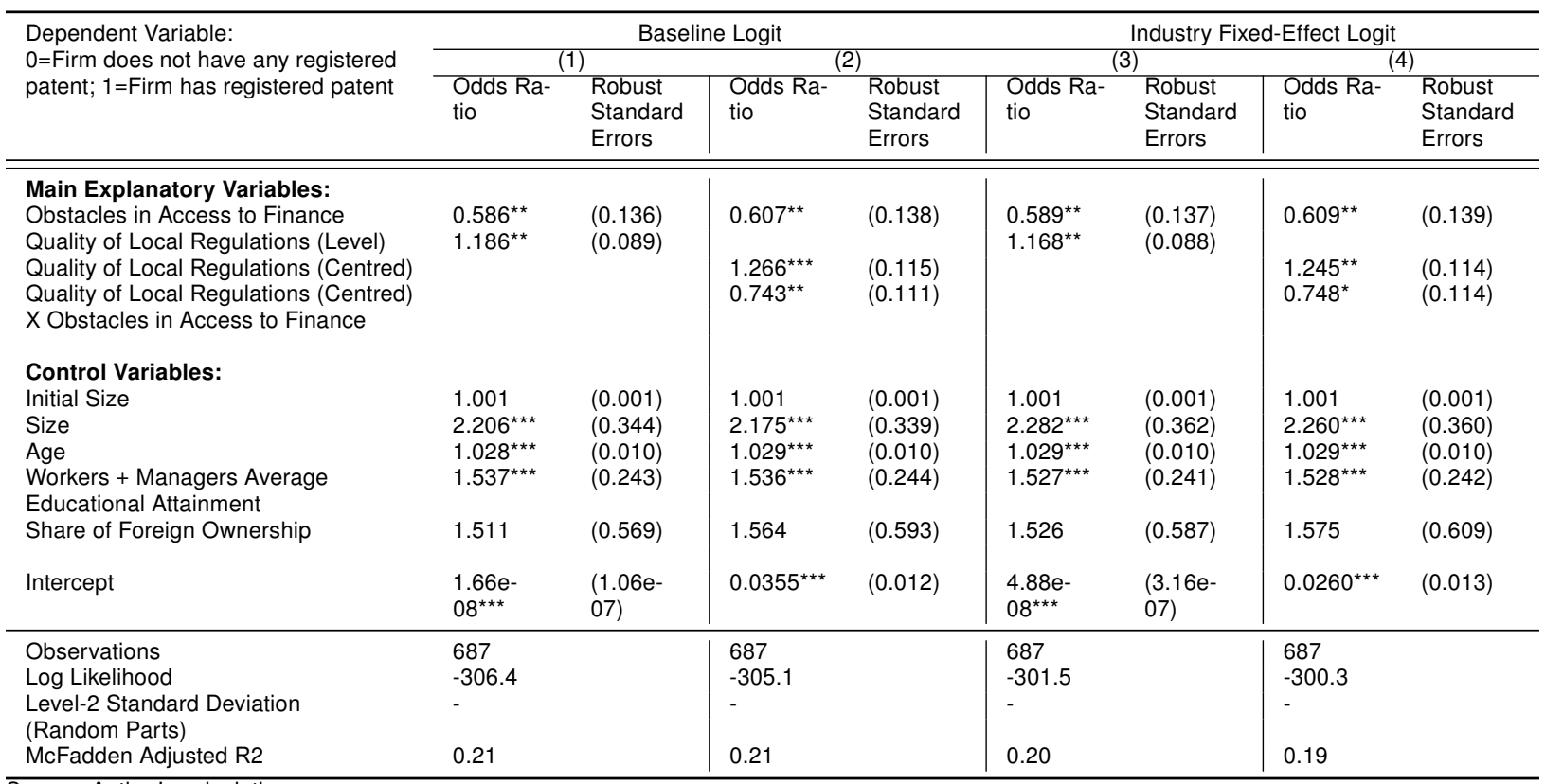

Source: Author's calculation

Note: Robust standard errors in parantheses; ${ }^{* * *} p<0.01,{ }^{* *} p<0.05,{ }^{*} p<0.10$

Table 4: Determinants of Innovative Activities: Logistic Regressions

\begin{tabular}{|c|c|c|c|c|c|c|c|c|}
\hline \multirow{3}{*}{$\begin{array}{l}\text { Dependent Variable: } \\
\text { 0=Firm involves in no innovative activities; } \\
\text { 1=Firm involves in one innovative activities; } \\
\text { 2=Firm involves in two innovative activities; } \\
\text { 3=Firm involves in } 3 \text { innovative activities: } \\
\text { product innovation (patents) and process } \\
\text { innovation (ISO and use of foreign technology) }\end{array}$} & \multicolumn{4}{|c|}{ Baseline Ordered Logit } & \multicolumn{4}{|c|}{ Industry Fixed-Effect Ordered Logit } \\
\hline & \multicolumn{2}{|c|}{$(5)$} & \multicolumn{2}{|c|}{$(6)$} & \multicolumn{2}{|c|}{$(7)$} & \multicolumn{2}{|c|}{$(8)$} \\
\hline & $\begin{array}{l}\text { Odds } \\
\text { Ratio }\end{array}$ & $\begin{array}{l}\text { Robust } \\
\text { Standard } \\
\text { Errors }\end{array}$ & $\begin{array}{l}\text { Odds } \\
\text { Ratio }\end{array}$ & $\begin{array}{l}\text { Robust } \\
\text { Standard } \\
\text { Errors }\end{array}$ & $\begin{array}{l}\text { Odds } \\
\text { Ratio }\end{array}$ & $\begin{array}{l}\text { Robust } \\
\text { Standard } \\
\text { Errors }\end{array}$ & $\begin{array}{l}\text { Odds } \\
\text { Ratio }\end{array}$ & $\begin{array}{l}\text { Robust } \\
\text { Standard } \\
\text { Errors }\end{array}$ \\
\hline \multicolumn{9}{|l|}{ Main Explanatory Variables: } \\
\hline Obstacles in Access to Finance & 0.728 & $(0.156)$ & 0.755 & $(0.159)$ & 0.744 & $(0.162)$ & 0.771 & $(0.165)$ \\
\hline Quality of Local Regulations (Level) & 1.118 & $(0.077)$ & & & 1.113 & $(0.077)$ & & \\
\hline Quality of Local Regulations (Centred) & & & $1.201^{\star *}$ & $(0.096)$ & & & $1.190^{\star \star}$ & $(0.096)$ \\
\hline $\begin{array}{l}\text { Quality of Local Regulations (Centred) X } \\
\text { Obstacles in Access to Finance }\end{array}$ & & & $0.724^{\star \star}$ & $(0.108)$ & & & $0.739^{\star}$ & $(0.114)$ \\
\hline \multicolumn{9}{|l|}{ Control Variables: } \\
\hline Initial Size & $1.001^{* *}$ & $(0.000)$ & $1.001^{\star *}$ & $(0.000)$ & $1.001^{\star *}$ & $(0.000)$ & $1.001^{\star *}$ & $(0.000)$ \\
\hline Size & $3.239^{\star \star \star}$ & $(0.502)$ & $3.181^{* * *}$ & $(0.491)$ & $3.290^{\star \star \star}$ & $(0.515)$ & $3.250^{\star * *}$ & $(0.507)$ \\
\hline Age & $1.022^{\star * \star}$ & $(0.008)$ & $1.023^{\star * *}$ & $(0.008)$ & $1.023^{\star \star \star}$ & $(0.008)$ & $1.024^{\star \star \star}$ & $(0.008)$ \\
\hline Workers + Managers Average Educational Attainment & $1.849^{* \star *}$ & $(0.264)$ & $1.873^{\star \star \star}$ & $(0.272)$ & $1.835^{\star \star \star}$ & $(0.265)$ & $1.857^{\star \star \star}$ & $(0.273)$ \\
\hline Share of Foreign Ownership & $3.425^{\star * *}$ & -1.244 & $3.603^{\star * *}$ & -1.322 & $3.493^{\star * *}$ & -1.258 & $3.665^{\star \star *}$ & -1.338 \\
\hline Observations & 686 & & 686 & & 686 & & 686 & \\
\hline Log Likelihood & -482.2 & & -480.4 & & -477.6 & & -476.1 & \\
\hline Level-2 Standard Deviation (Random Parts) & - & & - & & - & & - & \\
\hline McFadden Adjusted R2 & 0.23 & & 0.23 & & 0.23 & & 0.22 & \\
\hline
\end{tabular}

Source: Author's calculation

Note: Robust standard errors in parantheses; ${ }^{* * *} p<0.01,{ }^{* *} p<0.05,{ }^{*} p<0.10$ 
licenced technology). Therefore, it was likely that the non-significance of access to finance in estimation (6) was driven by the process innovation parts of the index. Involvement in process innovation is likely to be cheaper to finance, thus it was likely that firms facing access to finance as major obstacle could still bear the costs of either acquiring international quality certification or foreign-licensed technology. However, when it comes to product innovation such as patents, financing becomes a significant issue. This explains why access to finance was significant in product innovation regressions while they were not found to be significant in innovation index regressions. We also checked the robustness of our findings by incorporating industry fixed effects. As shown in estimation (7) and (8) in Table 4, controlling for industry fixed effects did not alter the results, except for the significance level of the interaction term which was now at $10 \%$.

\subsection{Innovative Activities Estimates: Alternative Econometric Estima- tions}

In the previous sub-section, we present the estimation of the innovative activities regressions using ordinal logit. Recall that our innovation index was basically a count index. We coded 0 if a firm did not engage in any innovative activities, while we coded 3 if a firm was involved in all three types of innovative activities. Thus, we basically counted the number of innovative activities performed by a firm. If we consider our innovation index as a count variable, then we can perform Poisson regressions which can also act as robustness checks for our innovation index's ordered logit regressions. Figure 12 depicts the distribution of our innovation index scores. It does seem to have a Poisson distribution.

Table 5 displays the results of our Poisson regressions estimates. For baseline regressions as shown in estimation (9) and (10), we found similar results to the estimates using ordered logit. We still found no evidence of any individual effect from access to finance and quality of local regulations in estimation (9). On the other hand, as shown in estimation (10), we also still found that firms located in a province with above average local institutional quality were more likely to have more innovative activities. Finally, we still found the evidence that firms facing access to finance as major obstacle were disproportionately worse off in better local institutional quality environment.

Once we controlled for industry fixed effects, our Poisson regressions estimates showed significant effects of access to finance as depicted in estimation (11) and (12) of Table 5. Estimation (11) shows that firms facing financial obstacles had $16 \%$ less likelihood to engage in more types of innovative activities. Estimation (12) displays that the negative effect of access to finance as major obstacle was still robust even after following the inclusion of the interaction term. Hence, the results of estimation (12) mimic the findings found in product innovation regressions. For all estimates, we conducted overdispersion tests that supported the hypothesis of the appropriability of our Poisson regression estimates.

We show in this sub-section that access to finance matters to innovative activities. There was also evidence that firms without problems in access to finance were better off in a better local institutional environment, confirming the asymmetric effect of institutional quality depending on firm capability to gain access to external financial resources.

\subsection{Do SMEs and Large Firms Differ?}

Firms may have different pattern on their innovation determinants depending on their size (Acs \& Audretsch 1988). Nevertheless, such claim is not universal as Van Dijk et al. (1997) argued that the conclusion that firm's innovation determinants differ between small and large firms obtained by Acs \& Audretsch (1988) is country specific. In the case of the US, Acs \& Audretsch (1988) found systematic differences in the determinants of innovation between small and large firms. In contrast, in the case of Netherlands, Van Dijk et al. (1997) did not find any systematic differences of innovation determinants between small and large firms. In this sub-section, we explore the case for Indonesia.

To disentangle the possibility that SMEs and large firms have different innovation determinants, we ran separate regressions for each group. The regression models were the same as previous regressions in which we also included the firm's characteristics as control variables. Table 6 provides 


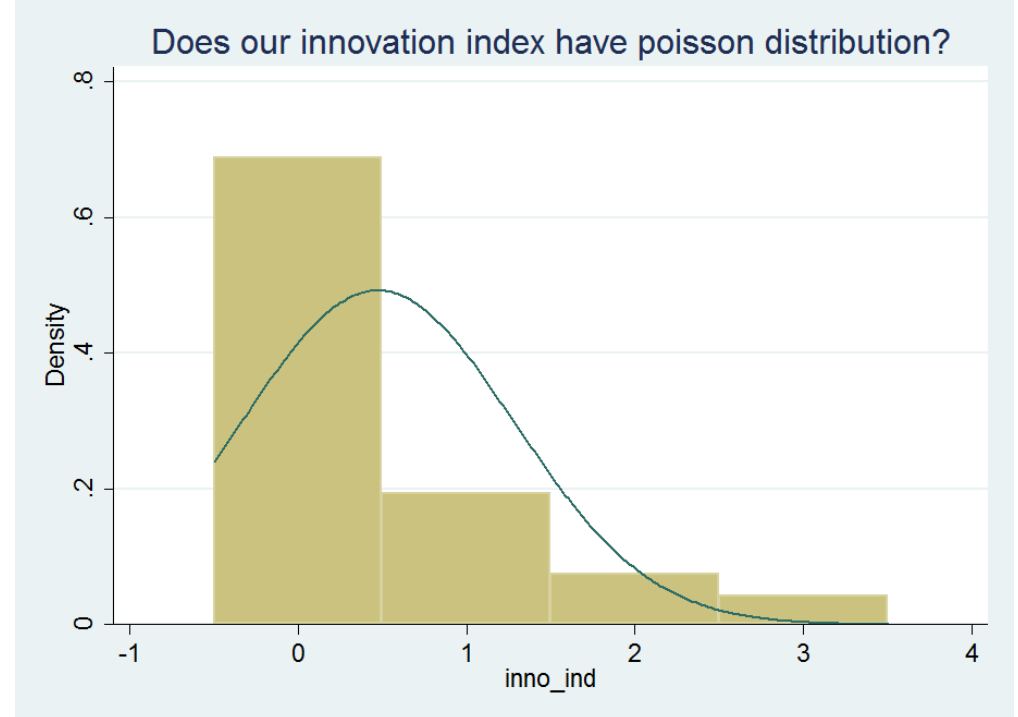

Figure 12: Distribution of Innovation Index Scores

Source: Author's calculation

Table 5: Determinants of Innovative Activities: Poisson Regressions

\begin{tabular}{|c|c|c|c|c|c|c|c|c|}
\hline \multirow{4}{*}{$\begin{array}{l}\text { Dependent Variable: } \\
0=\text { Firm involves in no innovative activities; } \\
1=\text { Firm involves in one innovative activities; } \\
2=\text { Firm involves in two innovative activities; } \\
3=\text { Firm involves in } 3 \text { innovative activities: } \\
\text { product innovation (patents) and process } \\
\text { innovation (ISO and use of foreign technology) }\end{array}$} & \multicolumn{4}{|c|}{ Baseline Poisson } & \multicolumn{4}{|c|}{ Industry Fixed-Effect Poisson } \\
\hline & \multicolumn{2}{|c|}{ (9) } & \multicolumn{2}{|c|}{$(10)$} & \multicolumn{2}{|c|}{$(11)$} & \multicolumn{2}{|c|}{$(12)$} \\
\hline & Tncidence- & Robust & Tncidence- & Robust & Tncidence- & Robust & Tncidence- & Robust \\
\hline & $\begin{array}{l}\text { Rate } \\
\text { Ratio }\end{array}$ & $\begin{array}{l}\text { Standard } \\
\text { Errors }\end{array}$ & $\begin{array}{l}\text { Rate } \\
\text { Ratio }\end{array}$ & $\begin{array}{l}\text { Standard } \\
\text { Errors }\end{array}$ & $\begin{array}{l}\text { Rate } \\
\text { Ratio }\end{array}$ & $\begin{array}{l}\text { Standard } \\
\text { Errors }\end{array}$ & $\begin{array}{l}\text { Rate } \\
\text { Ratio }\end{array}$ & $\begin{array}{l}\text { Standard } \\
\text { Errors }\end{array}$ \\
\hline \multicolumn{9}{|l|}{ Main Explanatory Variables: } \\
\hline Obstacles in Access to Finance & 0.808 & $(0.113)$ & 0.825 & $(0.106)$ & $0.838^{\star *}$ & $(0.063)$ & $0.850^{\star *}$ & $(0.070)$ \\
\hline Quality of Local Regulations (Level) & 1.058 & $(0.046)$ & & & 1.058 & $(0.049)$ & & \\
\hline Quality of Local Regulations (Centred) & & & $1.113^{\star *}$ & $(0.054)$ & & & $1.109^{*}$ & $(0.068)$ \\
\hline $\begin{array}{l}\text { Quality of Local Regulations (Centred) X } \\
\text { Obstacles in Access to Finance }\end{array}$ & & & $0.794^{\star \star \star}$ & $(0.063)$ & & & $0.807^{\star * \star}$ & $(0.066)$ \\
\hline \multicolumn{9}{|l|}{ Control Variables: } \\
\hline Initial Size & 1.000 & $(0.000)$ & 1.000 & $(0.000)$ & 1.000 & $(0.000)$ & 1.000 & $(0.000)$ \\
\hline Size & $2.212^{\star \star \star}$ & $(0.217)$ & $2.172^{\star \star \star}$ & $(0.208)$ & $2.190^{\star \star \star}$ & $(0.136)$ & $2.163^{\star \star \star}$ & $(0.139)$ \\
\hline Age & $1.009^{\star \star \star}$ & $(0.004)$ & $1.010^{\star \star \star}$ & $(0.004)$ & $1.011^{\star \star \star}$ & $(0.003)$ & $1.011^{* * *}$ & $(0.003)$ \\
\hline $\begin{array}{l}\text { Workers + Managers Average } \\
\text { Educational Attainment }\end{array}$ & $1.493^{\star \star \star}$ & $(0.129)$ & $1.494^{\star \star \star}$ & $(0.128)$ & $1.498^{\star \star \star}$ & $(0.168)$ & $1.499^{* \star \star}$ & $(0.169)$ \\
\hline Share of Foreign Ownership & $1.565^{\star \star \star}$ & $(0.197)$ & $1.618^{\star \star \star}$ & $(0.201)$ & $1.575^{\star \star \star}$ & $(0.088)$ & $1.617^{\star \star \star}$ & $(0.117)$ \\
\hline Test for Overdispersion (prob > chi2) & 593.02 & $(0.992)$ & 634.66 & $(0.882)$ & - & & - & \\
\hline Observations & 686 & & 686 & & 686 & & 686 & \\
\hline Log Likelihood & -494.9 & & -492.6 & & -472.3 & & -470.4 & \\
\hline McFadden Adjusted R2 & 0.25 & & 0.25 & & - & & - & \\
\hline
\end{tabular}

Source: Author's calculation

Note: Robust standard errors in parantheses; ${ }^{* \star *} p<0.01,{ }^{* *} p<0.05,{ }^{*} p<0.10$ 
Table 6: Small-Medium Firms vs Large Firms Estimates

\begin{tabular}{|c|c|c|c|c|}
\hline \multirow{4}{*}{$\begin{array}{l}\text { Dependent Variable: } \\
0=\text { Firm does not have any registered patent; } \\
1=\text { Firm has registered patent }\end{array}$} & \multicolumn{4}{|c|}{ Binary Logit } \\
\hline & \multirow{2}{*}{\multicolumn{2}{|c|}{ (13) }} & \multicolumn{2}{|c|}{ (14) } \\
\hline & & & \multicolumn{2}{|c|}{ Large Firms } \\
\hline & Odds Ratio & $\begin{array}{l}\text { Robust Stan- } \\
\text { dard Errors }\end{array}$ & Odds Ratio & $\begin{array}{l}\text { Robust Stan- } \\
\text { dard Errors }\end{array}$ \\
\hline \multicolumn{5}{|l|}{ Main Explanatory Variables: } \\
\hline Obstacles in Access to Finance & $0.580^{\star *}$ & $(0.159)$ & 0.720 & $(0.326)$ \\
\hline Quality of Local Regulations (Centred) & 1.169 & $(0.117)$ & $1.485^{\star \star}$ & $(0.269)$ \\
\hline Quality of Local Regulations (Centred) X Obstacles in Access to Finance & 0.864 & $(0.153)$ & 0.606 & $(0.197)$ \\
\hline Observations & 531 & & 156 & \\
\hline Log Likelihood & -201.0 & & -99.6 & \\
\hline McFadden R2 & 0.16 & & 0.05 & \\
\hline \multirow{4}{*}{$\begin{array}{l}\text { Dependent Variable: } \\
\text { 0=Firm involves in no innovative activities; } \\
\text { 1=Firm involves in one innovative activities; } \\
\text { 2=Firm involves in two innovative activities; } \\
3=\text { Firm involves in } 3 \text { innovative activities: } \\
\text { product innovation (patents) and process innovation } \\
\text { (ISO and use of foreign technology) }\end{array}$} & \multicolumn{4}{|c|}{ Poisson } \\
\hline & \multirow{2}{*}{\multicolumn{2}{|c|}{$\begin{array}{l}\text { (15) } \\
\text { SMEs }\end{array}$}} & \multicolumn{2}{|c|}{ (16) } \\
\hline & & & & Firms \\
\hline & IRR & $\begin{array}{l}\text { Robust } \\
\text { Standard } \\
\text { Errors }\end{array}$ & IRR & $\begin{array}{l}\text { Robust } \\
\text { Standard } \\
\text { Errors }\end{array}$ \\
\hline \multicolumn{5}{|l|}{ Main Explanatory Variables: } \\
\hline Obstacles in Access to Finance & 0.734 & $(0.142)$ & 0.960 & $(0.156)$ \\
\hline Quality of Local Regulations (Centred) & 1.078 & $(0.077)$ & $1.116^{*}$ & $(0.070)$ \\
\hline Quality of Local Regulations (Centred) X Obstacles in Access to Finance & 0.997 & $(0.129)$ & $0.759^{\star \star \star}$ & $(0.067)$ \\
\hline Observations & 531 & & 155 & \\
\hline Log Likelihood & -280.0 & & -210.4 & \\
\hline McFadden R2 & 0.14 & & 0.04 & \\
\hline
\end{tabular}

Note: Robust standard errors in parantheses; ${ }^{* * *} p<0.01,{ }^{* *} p<0.05,{ }^{*} p<0.10$

Other controls include initial size, age, workers+managers average educational attainment, and share of foreign ownership

the results. We started with product innovation determinants. Estimation (13) shows the results for SMEs firm sample whereas estimation (14) displays the results for large firms. As expected, access to finance was a more relevant issue for SMEs. Estimation (13) presents that SMEs facing major obstacle in access to finance were $42 \%$ less likely to have product innovation. Meanwhile, quality of local institutions did not seem to have significant impact on SMEs' product innovation. This result indicates that financial constraint is a bigger issue for SMEs to engage in product innovation. Since product innovation is costly, SMEs may need significant amount of external financing to support the activity. Because SMEs are more likely to have access to finance as their major obstacles, such financial constraints affect negatively on SMEs' ability to engage in product innovation. Meanwhile, to explain the non-significant effect of quality of local regulations index, it may be the case that SMEs do not fully enjoy the positive impact of better institutional quality of their business environment. It is possible that better local institutional quality which often translates into more formality does not nec- essarily help SMEs because they are less likely to have the resources capability to reap the benefit of better institutional quality.

Estimation (14), on the other hand, shows that quality of local regulations was critical for larger firms. Our model estimated that large firms located in provinces with above average regulatory quality had $49 \%$ more probability to engage in product innovation. Earlier, we discussed that the majority of large firms in our sample (85\%) did not regard access to finance as major obstacle. This is confirmed by estimation (14) where we did not find significant effect of obstacles in access to finance. Our previous regressions using all samples show that firms not facing obstacles in access to finance were disproportionately better off from better institutional quality. The results of estimation (14) confirm this argument. Larger firms face less problems in access to finance, and thus the positive impact of better quality of local regulations is mostly enjoyed by large firms. One possible explanation for this is that larger firms are more prepared and have more institutional capabil- 
ities to reap the benefit of better institutional quality of the business environment. Product innovation is not cheap investment. Therefore, businesses need to be sure that the perverse risks coming from external factors are minimal. Local regions with better institutional quality provide a more supportive business environment for firms to engage in product innovation. Moreover, better institutional quality provides a greater degree of certainty for businesses which is supremely important for firm's decision on whether to innovate or not. This explains why the quality of local regulations index was positive and significant for large firms regressions.

We performed the same exercise for innovation index as dependent variable. As displayed in estimation (15), we did not find significant effects of neither access to finance nor quality of local regulation for SMEs. This finding explains that the nonsignificant results of our main variables of interest (access to finance and quality of local regulations) in both ordered logit and Poisson regressions using all sample were driven by SMEs' firm sample. It is possible that an SME engages only in process innovation activities (ISO and foreign technology) while not being involved at all in product innovation. This likely cheaper innovative activity may not imply the necessity of external factors such as access to finance or quality of local regulations. In other words, other firm's characterictics (size, age, human capital, and foreign ownership) are already sufficient to explain variances in innovative activities of SMEs. In fact, these variables-not shown in Table 6-were indeed significant in estimation (15).

Finally, estimation (16) provides the results for large firms' innovation index regression. The quality of local regulations still mattered, however only after taking into account the access to finance. Consistent with the previous results, better local institutional quality was associated with more innovative activities. However, unlike estimation (14), in estimation (16) we found that the interaction term was significant with a negative sign. This indicates that access to finance matters for large firms if they want to engage in multiple innovative activities. Large firms that face major obstacle in terms of access to finance are less likely to engage in more innovative activities. Better local institutional quality increases the gap of innovative activities between large firms that have problems in obtaining external financing and those large firms which face no financial constraints. One possible explanation is that an additional innovative activity means extra costs for the firms. As more innovative activities imply larger financial resources to be allocated to such activities, large firms with limited financial resources and obstacles to obtain external financing are less likely to enjoy the positive impact of better institutional quality on innovation. These large firms are strained due to financial constraints they face despite being large firms, hence the gap of innovative activities between large firms with no financial constraints vis-a-vis those with obstacles in access to finance increases while local institutional quality improves.

\subsection{Unbundling the Effect of Local In- stitutional Quality and Access to Finance}

In this sub-section, we unbundle the effect of local institutional quality and access to finance. We computed the adjusted predictions of different categories of local institutional quality and access to finance. To do this, we created a categorical measure of local institutional quality (above average, average, and below average). If the score of quality of local regulations index was more than 1 point below the mean value, we coded it as "below average". Likewise, if the score was more than 1 point above the mean value, it was coded as "above average". Finally, if the score lied within -1 and 1 , we coded it as average.

Table 7 displays the adjusted predictions for product innovation and innovative activities regressions. The table is basically a $3 \times 2$ matrix in which quality of local regulations has 3 classifications (above average, average, and below average) while access to finance has 2 classifications (access to finance is not major obstacle and access to finance is major obstacle). For product innovation, we can see from Table 7 where firms that faced no obstacles in access to finance and were located in province with above average quality of regulations had $41 \%$ probability to have product innovation. At the other extreme, firms that faced major obstacle in access to finance and were located in province with below average quality of regulations only had $19 \%$ chance to have product innovation. Interestingly, the lowest change of having product innovation comes from a conditon where a firm was located in province with above 
average quality of local regulations but faced major obstacle in access to finance ( $11 \%$ chance). This indicates that better institutional quality asymmetrically benefits firms with better access to finance. Consequently, the gap in product innovation between financially constrained firms and nonfinancially constrained firms increases as institutional quality improves.

We also observed similar pattern for innovative activities. Firms located in province with above average quality of local regulations and no obstacles in access to finance had $78 \%$ chance to engage in innovative activities. On the other hand, below average quality of local regulations and major obstacles in access to finance only yielded $39 \%$ chance of involvement in innovative activities. Akin to estimates on product innovation, firms facing major obstacle in access to finance and yet located in province with above average quality of local regulations were the worst off ones with only $17 \%$ probability of engaging in innovative activities.

Another evidence that we can draw from Table $\mathbf{7}$ is that improving access to finance gave more significant impact on innovation in terms of magnitude. We also see that the innovation gap between firms with problems in access to finance and those without such problems grew as institutional quality improved. It ranged from $3 x$ difference for product innovation (0.09 row difference to 0.30 ) and $4 x$ difference for innovative activities $(0.15$ row difference to 0.61 ). Quality of local regulations was important, but it seemed more urgent to remove obstacles and barriers in access to finance since the estimated magnitude was much greater. Removal of barriers to finance also reduced the asymmetrical effect of better institutional quality. In any case, the first best condition is, as expected, to have better institutional quality and no obstacles in access to finance-a virtuous joint impact.

\section{Conclusions}

Our empirical analyses provide robust evidence on the positive impact of better local institutional quality, as measured by local regulations, and access to finance on innovation. Both variables were universally significant in influencing product innovation. Meanwhile, for total innovative activities that measure both product and process innovation, the results were dependent on model specification. However, we obtained significant results for innovative activities once we controlled for industry fixed effects and performed Poisson regression (innovation index as a count variable). We have also shown that access to finance and quality of regulations matter differently for firms of different size. The former is critical for SMEs whereas the later is more relevant for large firms. We have also provided an exercise to unbundle the varying implications of access to finance and quality of local regulations under different scenarios.

Regarding causality, we believe our estimates for quality of local regulations did not suffer from reverse causality. It is unlikely for firm's innovation to influence the quality of local regulations. Moreover, the quality of local regulations index was constructed based on legal analysis. This approach shares the spirit of Romer \& Romer (2010) who proposed the use of careful and rigorous desk study on taxation policies based on narrative/documents records. They argued that such approach lessens the omitted variable bias and weak exogeneity problem. Nevertheless, we do admit that unobserved firm characteristics might drive the results of access to finance. Unfortunately, due to the cross-sectional nature of our data, we were not able to control for any time-invariant unobserved characteristics of firm to reduce any potential endogeneity problem with access to finance. We did, however, attempt to ameliorate the problem by controlling for firm's initial size as well as other firm's characteristics as control variables. We also performed several robustness checks by controlling for industry fixed effects and running alternative econometric estimates for innovation activities. Although these strategies do not fully eliminate the endogeneity problem, they do help ameliorate such problems and thus give meaningful and robust estimates and associations (Almeida \& Fernandes 2008; Ayyagari, Demirguc-Kunt \& Maksimovic 2011).

The results of this paper also have critical policy relevance. We have shown that external factorsi.e., access to finance and institutional qualitymatter for innovation. However, the relationship is more complicated than it looks. We found that better institutional quality supported innovation disproportionately for firms not facing obstacles in external financing. The innovation gap between firms facing obstacles in finance and those that were 
Table 7: Adjusted Predictions of Quality of Local Regulations and Access to Finance

\begin{tabular}{|c|c|c|c|c|c|c|}
\hline \multirow{3}{*}{ Province } & \multicolumn{3}{|c|}{ Product Innovation } & \multicolumn{3}{|c|}{ Innovative Activities } \\
\hline & \multicolumn{2}{|c|}{ Access to Finance is } & \multirow{2}{*}{$\begin{array}{l}\text { Row } \\
\text { Difference }\end{array}$} & \multicolumn{2}{|c|}{ Access to Finance is } & \multirow{2}{*}{$\begin{array}{l}\text { Row } \\
\text { Difference }\end{array}$} \\
\hline & $\begin{array}{l}\text { Not Major } \\
\text { Obstacle }\end{array}$ & $\begin{array}{l}\text { Major Ob- } \\
\text { stacle }\end{array}$ & & $\begin{array}{l}\text { Not Major } \\
\text { Obstacle }\end{array}$ & $\begin{array}{l}\text { Major Ob- } \\
\text { stacle }\end{array}$ & \\
\hline Above Average Quality of Regulations & 0.41 & 0.11 & 0.30 & 0.78 & 0.17 & 0.61 \\
\hline Average Quality of Regulations & 0.34 & 0.14 & 0.20 & 0.65 & 0.26 & 0.39 \\
\hline Below Average Quality of Regulations & 0.28 & 0.19 & 0.09 & 0.54 & 0.39 & 0.15 \\
\hline Average of Column Differences & 0.07 & -0.04 & - & 0.12 & -0.11 & - \\
\hline
\end{tabular}

Source: Author's calculation

Note: All adjusted predictions (margins) are significant at $1 \%$ level.

Product innovation is estimated with binary logit. Innovation activities index is estimated with poisson regression.

The predicted average marginal effects are estimated controlling for initial size, size, age, workers+managers average educational attainment, share of foreign ownership, industry fixed-effects, and interaction term between quality of regulations and access to finance.

not financially constrained became larger as institutional quality improved. The policy implication of this finding is that simply aiming for improvement in institutional quality is not the first best policy option.

Our investigation unveils that the effects of access to finance and quality of regulations differ by firm size. Access to finance is more relevant for SMEs whereas institutional quality matters more for large firms. Although better institutional quality and no obstacles in access to finance are the ideal conditon in which policymakers need to aim, our empirical exercises have shown that the matter is more complicated. We have shown that improving access to finance has a greater magnitude to improve the probability for firms to engage in innovative activities. In addition, improvement in access to finance also reduces the innovation gap between firms that face obstacles to obtain external financing and firms with no financial constraints.

We do not argue that institutional quality is less important. It is critical and it has a positive impact on innovation. However, if the goal is both to boost innovation and reduce innovation gap among firms, then improving access to finance is supremely critical. Improvement in institutional quality without any significant removal of barriers to obtain external financing will lead to larger innovation gap. Thus, the policy goal to increase the quality of local regulations and to reduce frictions in the credit markets by reducing the sources of asymmetric information may well be a virtuous policy mix to promote innovation and ensure that as many firms as possible engage in innovative activities.

\section{References}

[1] Abraham, J \& Davis, C 2007, 'Interpellative Sociology of Pharmaceuticals: Problems and Challenges for Innovation and Regulation in the 21st Century', Technology Analysis and Strategic Management, vol. 19, no. 3, pp. 387-402.

[2] Acemoglu, D, Johnson, S \& Robinson, JA 2001, 'The Colonial Origins of Comparative Development: An Empirical Investigation', American Economic Review, vol. 91, no. 5, pp. 1369-1401.

[3] Acemoglu, D \& Robinson, JA 2008, 'The Role of Institutions in Growth and Development', Commission on Growth and Development Working Paper No. 10, World Bank, Washington D.C.

[4] Acs, ZJ \& Audretsch, DB 1987, 'Innovation, Market Structure, and Firm Size', Review of Economics and Statistics, vol. 69 , no. 4 , pp. 567-574.

[5] Acs, ZJ \& Audretsch, DB 1988, 'Innovation in Large and Small Firms: An Empirical Analysis', American Economic Review, vol. 78, no. 4, pp. 678-690.

[6] Almeida, R \& Fernandes, AM 2008, 'Openness and Technological Innovations in Developing Countries: Evidence from Firm-Level Surveys', Journal of Development Studies, vol. 44, no. 5, pp. 701-727.

[7] Anderlini, L, Felli, L, Immordino, G \& Riboni, A 2013, 'Legal Institutions, Innovation and Growth', International Economic Review, (forthcoming).

[8] Archibugi, D \& Pianta, M 1996, 'Measuring Technological Change Through Patents and Innovation Surveys', Technovation, vol. 16, no. 9, pp. 451-468.

[9] Asia Foundation 2007, Making Sense of Business Licensing in Indonesia, Foundation, Jakarta.

[10] Ayyagari, M, Demirguc-Kunt, A \& Maksimovic, V 2011, 'Firm Innovation in Emerging Markets: The Role of Finance, Governance and Competititon', Journal of Financial and Quantitative Analysis, vol. 46, no. 6, pp. 1545-1580.

[11] Bartel, A, Ichniowski, C \& Shaw, K 2007, 'How Does Information Technology Affect Productivity? Plant-Level Comparisons of Product Innovation, Process Improvement, and Worker Skills', Quarterly Journal of Economics, vol. 12, no. 4, pp. 1721-1758.

[12] Beck, T 2008, 'The Econometrics of Finance and Growth', Policy Research Working Paper Series No. 4608, World Bank, Washington D.C.

[13] Benfratello, L, Schiantarelli, F \& Sembenelli, A 2008,

Economics and Finance in Indonesia Vol. 61 No. 3, December 2015 
Description of Variables \& Summary Statistics

\begin{tabular}{|c|c|c|c|c|c|c|}
\hline Variable & & $O b$ & Yom & Std Den & Yir & Yax \\
\hline $\begin{array}{l}\text { Patents }(1=\text { if the establishment has at least one patent } \\
\text { registered in any country; } 0=\text { otherwise })\end{array}$ & \multirow{12}{*}{ World Bank Enterprise Survey (2009) } & 849 & 0.25 & 0.43 & 0 & 1 \\
\hline $\begin{array}{l}\text { Quality Certification }(1=\text { if the establishment has } \\
\text { internationally recognised quality certification such as } \\
\text { ISO; } 0=\text { otherwise })\end{array}$ & & 856 & 0.11 & 0.31 & 0 & 1 \\
\hline $\begin{array}{l}\text { Foreign Technology ( } 1=\text { if the establishment uses } \\
\text { technology licensed from a foreign-owned company } \\
\text { excluding office software; } 0=\text { otherwise })\end{array}$ & & 854 & 0.11 & 0.32 & 0 & 1 \\
\hline $\begin{array}{l}\text { Innovation Index ( } 0=\text { Firm involves in no innovative } \\
\text { activities; } 1=\text { Firm involves in one innovative activities; } \\
2=\text { Firm involves in two innovative activities; } 3=\text { Firm } \\
\text { involves in } 3 \text { innovative activities: product innovation } \\
\text { (patents) \& process innovation (ISO \& use of foreign } \\
\text { technologv)) }\end{array}$ & & 848 & 0.47 & 0.81 & 0 & 3 \\
\hline Initial Size (number of full-time employees at start-up) & & 823 & 48.26 & 140.64 & 1 & 1800 \\
\hline Size $(1=$ small $(5-19) ; 2=$ medium $(20-99) ; 3=$ large $(>99))$ & & 856 & 1.68 & 0.80 & 1 & 3 \\
\hline Age (age of establishment as of 2009) & & 838 & 17.95 & 12.04 & 2 & 97 \\
\hline $\begin{array}{l}\text { Workers Average Educational Attainment }(0=\text { nine years } \\
\text { of education or less; } 1 \text { = beyond nine years of } \\
\text { education) }\end{array}$ & & 823 & 0.30 & 0.46 & 0 & 1 \\
\hline $\begin{array}{l}\text { Top Managers Average Educational Attainment } \\
(0=\text { secondary school or lower; } 1=\text { vocational school or } \\
\text { tertiary education })\end{array}$ & & 851 & 0.38 & 0.49 & 0 & 1 \\
\hline $\begin{array}{l}\text { Workers }+ \text { Managers Average Educational Attainment } \\
(0=\text { low; } 1=\text { mixed; } 2=\text { high })\end{array}$ & & 819 & 0.69 & 0.79 & 0 & 2 \\
\hline $\begin{array}{l}\text { Share of Foreign Ownership ( } 0=\text { less than } 10 \% ; 1=\text { above } \\
10 \%)\end{array}$ & & 853 & 0.06 & 0.24 & 0 & 1 \\
\hline $\begin{array}{l}\text { Obstacles in Access to Finance ( } 1=\text { if access to finance is } \\
\text { the establishment's biggest obstacle; } 0=\text { otherwise })\end{array}$ & & 760 & 0.41 & 0.49 & 0 & 1 \\
\hline $\begin{array}{l}\text { Quality of Local Regulations ( } 0-100 \text {; larger score } \\
\text { indicates better quality) }\end{array}$ & KPPOD Local Economic Governance Survey (2007) & 856 & 85.18 & 1.34 & 80.97 & 86.32 \\
\hline
\end{tabular}

Figure 13: Description of Variables and Summary Statistics

Source: Author's calculation

Table 8: Correlation Matrix

\begin{tabular}{|c|c|c|c|c|c|c|c|}
\hline & Initial Size & Size & Age & $\begin{array}{l}\text { Education } \\
\text { (Workers+ } \\
\text { Managers) }\end{array}$ & $\begin{array}{r}\text { Foreign } \\
\text { Ownership }\end{array}$ & $\begin{array}{r}\text { Quality of } \\
\text { Local } \\
\text { Regulation }\end{array}$ & $\begin{array}{r}\text { Obstacles in } \\
\text { Access to } \\
\text { Finance }\end{array}$ \\
\hline Initial Size & 1 & & & & & & \\
\hline Size & $\begin{array}{r}-\overline{19} \\
(0.4619 \\
(0.00)\end{array}$ & $\begin{array}{r}1 \\
-\end{array}$ & & & & & \\
\hline Age & $\begin{array}{r}0.1365 \\
(0.00)\end{array}$ & $\begin{array}{r}0.2539 \\
(0.00)\end{array}$ & $\begin{array}{c}1 \\
-\end{array}$ & & & & \\
\hline Education (Workers+Managers) & $\begin{array}{r}0.3125 \\
(0.00)\end{array}$ & $\begin{array}{r}0.6123 \\
(0.00)\end{array}$ & $\begin{array}{r}0.0993 \\
(0.00)\end{array}$ & $\begin{array}{r}1 \\
-\end{array}$ & & & \\
\hline Foreign Ownership & $\begin{array}{r}0.1503 \\
(0.00)\end{array}$ & $\begin{array}{r}0.2936 \\
(0.00)\end{array}$ & $\begin{array}{r}-0.0263 \\
(0.45)\end{array}$ & $\begin{array}{l}0.297 \\
(0.00)\end{array}$ & $\begin{array}{r}1 \\
-\end{array}$ & & \\
\hline Quality of Local Regulation & $\begin{array}{r}0.0089 \\
(0.80)\end{array}$ & $\begin{array}{r}0.0099 \\
(0.77)\end{array}$ & $\begin{array}{r}0.0631 \\
(0.07)\end{array}$ & $\begin{array}{r}-0.013 \\
(0.71)\end{array}$ & $\begin{array}{r}-0.0251 \\
(0.46)\end{array}$ & $\begin{array}{r}1 \\
-\end{array}$ & \\
\hline Obstacles in Access to Finance & $\begin{array}{r}-0.1875 \\
(0.00)\end{array}$ & $\begin{array}{r}-0.3276 \\
(0.00)\end{array}$ & $\begin{array}{r}-0.0664 \\
(0.07)\end{array}$ & $\begin{array}{r}-0.3175 \\
(0.00)\end{array}$ & $\begin{array}{r}-0.1433 \\
(0.00)\end{array}$ & $\begin{array}{r}0.1531 \\
(0.00)\end{array}$ & $\begin{array}{l}1 \\
-\end{array}$ \\
\hline
\end{tabular}

Note: Significance levels are in parentheses 
'Banks and Innovation: Microeconometric Evidence on Italian Firms', Journal of Financial Economics, vol. 90, no. 2, pp. 197-217.

[14] Blind, K 2012, 'The Influence of Regulations on Innovation: A Quantitative Assessment for OECD Countries', Research Policy, vol. 41, no. 2, pp. 391-400.

[15] Bloom, N \& Van Reenen, J 2007, 'Measuring and Explaining Management Practices across Firms and Countries', Quarterly Journal of Economics, vol. 122, no. 4, pp. 13511408.

[16] Bottazzi, L \& Da Rin, M 2002, 'Venture Capital in Europe and the Financing of Innovative Companies', Economic Policy, vol. 17, no. 34, pp. 229-270.

[17] Brodjonegoro, B 2004, 'Three Years of Fiscal Decentralization in Indonesia: Its Impacts on Regional Economic Development and Fiscal Sustainability'. Seminar Paper at the Department of Economics, University of Indonesia, (Mimeo).

[18] Butt, S 2010, 'Regional Autonomy and Legal Disorder: The Proliferation of Local Laws in Indonesia', Sydney Law Review, vol. 32, no. 2, pp. 177-191.

[19] Chataway, J, Tait, J \& Wield, D 2006, 'The Governance of Agro- and Pharmaceutical Biotechnology Innovation: Public Policy and Industrial Strategy', Technology Analysis and Strategic Management, vol. 18, no. 2, pp. 169-185.

[20] Cohen, WM 2010, 'Fifty Years of Empirical Studies of Innovative Activity and Performance' in Handbook of the EcOnomics of Innovation Vol. 1, eds BH Hall \& N Rosenberg, North Holland, Amsterdam, pp. 129-213.

[21] Cooke, P 2001, 'Regional Innovation Systems, Clusters, and the Knowledge Economy', Industrial and Corporate Change, vol. 10, no. 4, pp. 945-974.

[22] Dean, JC 2000, 'Fueling the Revolution: Commercial Bank Financing' in The Silicon Valley Edge: A Habitat for Innovation and Entrepreneurship, eds C-M Lee, WF Miller, MG Hancock \& HS Rowen, Stanford University Press, Stanford.

[23] Demirguc-Kunt, A \& Levine, R 1999, 'Bank-Based and Market-Based Financial Systems: Cross-Country Comparisons', Policy Research Working Paper Series No. 2143, World Bank, Washington D.C.

[24] Demirguc-Kunt, A \& Maksimovic, V 2002, 'Funding Growth in Bank-Based and Market-Based Financial Systems: Evidence from Firm Level Data', Journal of Financial Economics, vol. 65, no. 3, pp. 337-363.

[25] Djankov, S, Porta, RL, Lopez-De-Silanes, F \& Shleifer, A 2002, 'The Regulation of Entry', Quarterly Journal of Economics, vol. 117, no. 1, pp. 1-37.

[26] Djankov, S, McLiesh, C \& Ramalho, RM 2006, 'Regulation and Growth', Economics Letters, vol. 92, no. 3, pp. 395401.

[27] Dolfsma, W \& Seo, D 2013, 'Government Policy and Technological Innovation -A Suggested Typology', Technovation, vol. 33, no. 6-7, pp. 173-179.

[28] Fagerberg, J 2005, 'Innovation: A Guide to the Literature' in The Oxford Handbook of Innovation, eds J Fagerberg, DC Mowery \& RR Nelson, Oxford University Press, New York, pp. 1-26.

[29] Flanagan, K, Uyarra, E \& Laranja, M 2011, 'Reconceptualising the 'Policy Mix' for Innovation', Research Policy, vol. 40, no. 5, pp. 702-713.

[30] Florida, RL \& Kenney, M 1988, 'Venture Capital-Financed Innovation and Technological Change in the USA', Research Policy, vol. 17, no. 3, pp. 119-137.

[31] Glaeser, EL, La Porta, R, Lopez-De-Silanes, F \& Shleifer,
A 2004. 'Do Institutions Cause Growth?', Journal of Economic Growth, vol. 9, no. 3, pp. 271-303.

[32] Gorodnichenko, Y \& Schnitzer, M 2013, 'Financial Constraints and Innovation: Why Poor Countries Don't Catch Up', Journal of the European Economic Association, (forthcoming).

[33] Gorodnichenko, Y, Svejnar, J \& Terrell, K 2010, 'Globalization and Innovation in Emerging Markets', American Economic Journal: Macroeconomics, vol. 2, no. 2, pp. 194226.

[34] Hall, BH \& Lerner, J 2010, 'The Financing of R\&D and Innovation' in Handbook of the Economics of Innovation Vol. 1, eds $\mathrm{BH}$ Hall \& N Rosenberg, North Holland, Amsterdam, pp. 609-639.

[35] Helm, D 2006, 'Regulatory Reform, Capture, and the Regulatory Burden', Oxford Review of Economic Policy, vol. 22, no. 2, pp. 169-185.

[36] Henisz, WJ 2000, 'The Institutional Environment for Economic Growth', Economics and Politics, vol. 12, no. 1, pp. $1-31$.

[37] Herrera, AM \& Minetti, R 2007, 'Informed Finance and Technological Change: Evidence from Credit Relationships', Journal of Financial Economics, vol. 83, no. 1, pp. 223-269.

[38] Hoffman, K, Parejo, M, Bessant, J \& Perren, L 1998 , 'Small Firm, R\&D, Technology and Innovation in the UK: A Literature Review', Technovation, vol. 18, no. 1, pp. 3955.

[39] Houben, A \& Kakes, J 2002, 'ICT Innovation and Economic Performance: The Role of Financial Intermediation', Kyklos, vol. 55, no. 4, pp. 543-562.

[40] Hubbard, RG 1998, 'Capital-Market Imperfections and Investment', Journal of Economic Literature, vol. 36, no. 1, pp. 193-225.

[41] Huo, J \& Feng, H 2010, 'The Political Economy of Technological Innovation and Employment', Comparative Political Studies, vol. 43, no. 3, pp. 329-352.

[42] Hyytinen, A \& Toivanen, O 2005, 'Do Financial Constraints Hold Back Innovation and Growth? Evidence on the Role of Public Policy', Research Policy, vol. 34, no. 9, pp. 13851403.

[43] Jalilian, H, Kirkpatrick, C \& Parker, D 2007', 'The Impact of Regulation on Economic Growth in Developing Countries: A Cross-Country Analysis', World Development, vol. 35, no. 1, pp. 87-103.

[44] Jeng, LA \& Wells, PC 2000, 'The Determinants of Venture Capital Funding: Evidence Across Countries', Journal of Corporate Finance, vol. 6, no. 3, pp. 241-289.

[45] Kleinknecht, A, Van Montford, K \& Brouwer, E 2002, 'The Non-Trivial Choice between Innovation Indicators', Economics of Innovation and New Technology, vol. 11, no. 2, pp. 109-121.

[46] Knack, S \& Keefer, P 1995, 'Institutions and Economic Performance: Cross-Country Tests Using Alternative Institutional Measures', Economics and Politics, vol. 7, no. 3, pp. 207-227.

[47] Kortum, S \& Lerner, J 2000, 'Assessing the Contribution of Venture Capital to Innovation', RAND Journal of Economics, vol. 31, no. 4, pp. 674-692.

[48] KPPOD 2005. Investment Competitiveness of Regencies/Cities in Indonesia, 2005: Perceptions of the Business Community, Komite Pemantauan Pelaksanaan Otonomi Daerah.

[49] KPPOD 2007. Local Economic Governance in Indonesia: A Survey of Businesses in 243 Regencies/Cities 
in Indonesia, 2007, Komite Pemantauan Pelaksanaan Otonomi Daerah.

[50] KPPOD 2011. Local Economic Governance: A Survey of Business Operators in 245 Districts/Municipalities in Indonesia, Komite Pemantauan Pelaksanaan Otonomi Daerah.

[51] Lall, S 1992, 'Technological Capabilities and Industrialization', World Development, vol. 20, no. 2, pp. 165-186.

[52] Levine, R 2005, 'Finance and Growth: Theory and Evidence' in Handbook of Economic Growth: Volume 1A, eds $\mathrm{P}$ Aghion \& SN Durlauf, North Holland, Amsterdam, pp. 865-934.

[53] LPEM-FEUI 2007. Monitoring Investment Climate in Indonesia: A Report from the Mid 2006 Survey, Lembaga Penyelidikan Ekonomi dan Masyarakat-Fakultas Ekonomi Universitas Indonesia.

[54] Mahendra, E 2009, 'Financial Dependence, Macroeconomic Stability, and Firm Growth: What Policy Implications for Indonesia?', Economics and Finance in Indonesia, vol. 57, no. 2, pp. 219-254.

[55] Mairesse, J \& Mohnen, P 2010, 'Using Innovation Surveys for Econometric Analysis' in Handbook of the Economics of Innovation Vol. 2, eds BH Hall \& N Rosenberg, North Holland, Amsterdam, pp. 1129-1155.

[56] Mauro, P 1995, 'Corruption and Growth', Quarterly Journal of Economics, vol. 110, no. 3, pp. 681-712.

[57] Morck, R, Yeung, B \& Yu, W 2000, 'The Information Content of Stock Markets: Why Do Emerging Markets Have Synchronous Stock Price Movements?', Journal of Financial Economics, vol. 58, no. 1-2, pp. 215-260.

[58] Murray, GC \& Lott, J 1995, 'Have UK Venture Capitalists a Bias Against Investment in New Technology-Based Firms', Research Policy, vol. 24, no. 2, pp. 283-299.

[59] North, DC 1990, Institutions, Institutional Change, and Economic Performance, Cambridge University Press, New York.

[60] O'Sullivan, M 2005, 'Finance and Innovation' in The Oxford Handbook of Innovation, eds J Fagerberg, DC Mowery \& RR Nelson, Oxford University Press, New York, pp. 240-265.

[61] Prieger, JE 2002, 'Regulation, Innovation, and the Introduction of New Telecommunications Services', Review of Economics and Statistics, vol. 84, no. 4, pp. 704-715.

[62] Rodrik, D, Subramanian, A \& Trebbi, F 2004, 'Institutions Rule: The Primacy of Institutions Over Geography and Integration in Economic Development', Journal of Economic Growth, vol. 9, no. 2, pp. 131-165.

[63] Romer, CD \& Romer, DH 2010, 'The Macroeconomic Effects of Tax Changes: Estimates Based on a New Measure of Fiscal Shocks', American Economic Review, vol. 100, no. 3, pp. 763-801.

[64] Rowen, HS 2000, 'Serendipity or Strategy: How Technology and Markets Came to Favor Silicon Valley' in The Silicon Valley Edge: A Habitat for Innovation and Entrepreneurship, eds C-M Lee, WF Miller, MG Hancock \& HS Rowen, Stanford University Press, Stanford.

[65] Schumpeter, JA 1942, Capitalism, Socialism, and Democracy, Harper, New York.

[66] Schwab, K \& Sala-i-Martin, X 2012, The Global Competitiveness Report 2012-2013: Full Data Edition, World Economic Forum, Geneva.

[67] Segerstrom, PS 1991, 'Innovation, Imitation, and Economic Growth', Journal of Political Economy, vol. 99, no. 4, pp. 807-827.

[68] Sharma, S 2007, 'Financial Development and Innovation in Small Firms', Policy Research Working Paper Series No. 4350, World Bank, Washington D.C.

[69] Srholec, M 2011, 'A Multilevel Analysis of Innovation in Developing Countries', Industrial and Corporate Change, vol. 20, no. 6, pp. 1539-1569.

[70] Stiglitz, JE \& Weiss, A 1981, 'Credit Rationing in Markets with Imperfect Information', American Economic Review, vol. 71, no. 3, pp. 393-410.

[71] Taylor, MZ 2007, 'Political Decentralization and Technological Innovation: Testing the Innovative Advantages of Decentralized States', Review of Policy Research, vol. 24, no. 3, pp. 231-257.

[72] Tebaldi, E \& Elmslie, B 2013, 'Does Institutional Quality Impact Innovation? Evidence from Cross-Country Patent Grant Data', Applied Economics, vol. 45, no. 7, pp. 887900.

[73] Van Dijk, B, Den Hertog, R, Menkveld, B \& Roy Thurik, R 1997, 'Some New Evidence on the Determinants of Largeand Small-Firm Innovation', Small Business Economics, vol. 9, no. 4, pp. 335-343.

[74] Wignaraja, G 2002, 'Firm Size, Technological Capabilities and Market-oriented Policies in Mauritius', Oxford Development Studies, vol. 30, no. 1, pp. 87-104.

[75] World Bank \& International Finance Corporation 2012, Doing Business in Indonesia 2012, World Bank and International Finance Corporation, Washington D.C. 